\title{
15. MIDDLE MIOCENE TO QUATERNARY DIATOM BIOSTRATIGRAPHY OF DEEP SEA DRILLING PROJECT SITE 594, CHATHAM RISE, SOUTHWEST PACIFIC ${ }^{1}$
}

\author{
Paul F. Ciesielski, University of Florida ${ }^{2}$
}

\begin{abstract}
A diatom biostratigraphy is presented for middle Miocene through Quaternary sediments recovered from the Chatham Rise east of New Zealand's South Island. The upper $590 \mathrm{~m}$ of the $639.5-\mathrm{m}$ composite-section Site 594 represents approximately $16 \mathrm{~m} . \mathrm{y}$. and is characterized by moderately to very poorly preserved diatoms of antarctic to temperate af finity. Pliocene through Quaternary assemblages are poorly preserved and dominated by antarctic-subantarctic species which provide detailed biostratigraphic control. Recognized are 11 of 14 zones of the middle upper Miocene to Quaternary Neogene Southern Ocean diatom zonation (NSD 7-NSD 20) of Ciesielski (1983; this chapter).

Four Neogene Southern Ocean diatom zones (NSD 3-NSD 6) are recognized in the lower middle Miocene to middle upper Miocene of Site 594. Assemblages of this interval have a mixed high-latitude and temperate affinity; however, poor preservation limits correlation to high- and temperate-latitude zonal schemes.

Neogene North Pacific diatom zones and subzones of NNPD 3 through NNPD 5 (Barron, in press, b) are correlated to Neogene Southern Ocean diatom zones NSD 3 through NSD 7: the upper portions of the Actinocyclus ingens Zone (NNPD 3) is correlative to the upper Nitzschia maleinterpretaria Zone (NSD 3); the Denticulopsis lauta Zone (NNPD 4) and Subzones a and $\mathrm{b}$ are correlative to the lower Coscinodiscus lewisianus Zone (NSD 4); and the D. hustedtii-D. lauta Zone (NNPD 5) and its Subzones a through d encompass the upper $C$. lewisianus Zone (NSD 4), N. grossepunctata Zone (NSD 5), $N$. denticuloides Zone (NSD 6), and the lower D. hustedtii-D. lauta Zone (NSD 7).

A major disconformity spans the late Gilbert to early Gauss Chron (3.9-2.8 Ma). A second disconformity brackets the Miocene/Pliocene boundary; the section missing covers late Chron 5 and the early Gilbert chron (5.5-4.6 Ma). The remainder of the siliceous-fossil-bearing Miocene sediments at Site 594 appear to be correlative to lower paleomagnetic Chronozone 5 through upper Chronozone 16. Uppermost lower Miocene or lowermost middle Miocene sediments in the basal $50 \mathrm{~m}$ of Hole 594A are barren of diatoms.
\end{abstract}

\section{INTRODUCTION}

Site 594 is currently located in northern subantarctic waters immediately south of the Subtropical Convergence which separates the subantarctic from the cool-subtropical (temperate) water mass to the north. Upwelling associated with the Subtropical Convergence has produced high biogenic productivity, especially of the siliceous planktonic groups. As a result, diatoms are persistent and often abundant. This chapter describes the diatom biostratigraphy of Site 594, one of the best Neogene diatom sequences in the Southern Hemisphere.

Site $594\left(45^{\circ} 31.41^{\prime} \mathrm{S}, 174^{\circ} 56.88^{\prime} \mathrm{E}, 1204 \mathrm{~m}\right.$ water depth) is located at the southern margin of the Chatham Rise east of New Zealand's South Island (Fig. 1). The section studied consists of two holes cored to a maximum sub-bottom depth of $639.5 \mathrm{~m}$ (Fig. 2). Hole 594 consists of 53 cores obtained from 0 to $505.1 \mathrm{~m}$ sub-bottom depth, using the hydraulic piston corer (HPC) to $130.7 \mathrm{~m}$. Hole 594A was discontinuously cored to a subbottom depth of $495.5 \mathrm{~m}$; 11 cores were taken in the upper Miocene to Pleistocene intervals poorly recovered by Hole 594. Below $495.5 \mathrm{~m}$, Hole 594A was continuously drilled to termination of the hole at $639.5 \mathrm{~m}$. Depth relationships of cores from Hole 594 and 594A are shown in Figures 3-4, backpocket.

\footnotetext{
${ }^{1}$ Kennett, J. P., von der Borch, C. C., et al., Init. Repts. DSDP, 90: Washington (U.S. Govt, Printing Office).

2 Address: Department of Geology, University of Florida, Gainesville, FL 32611.
}

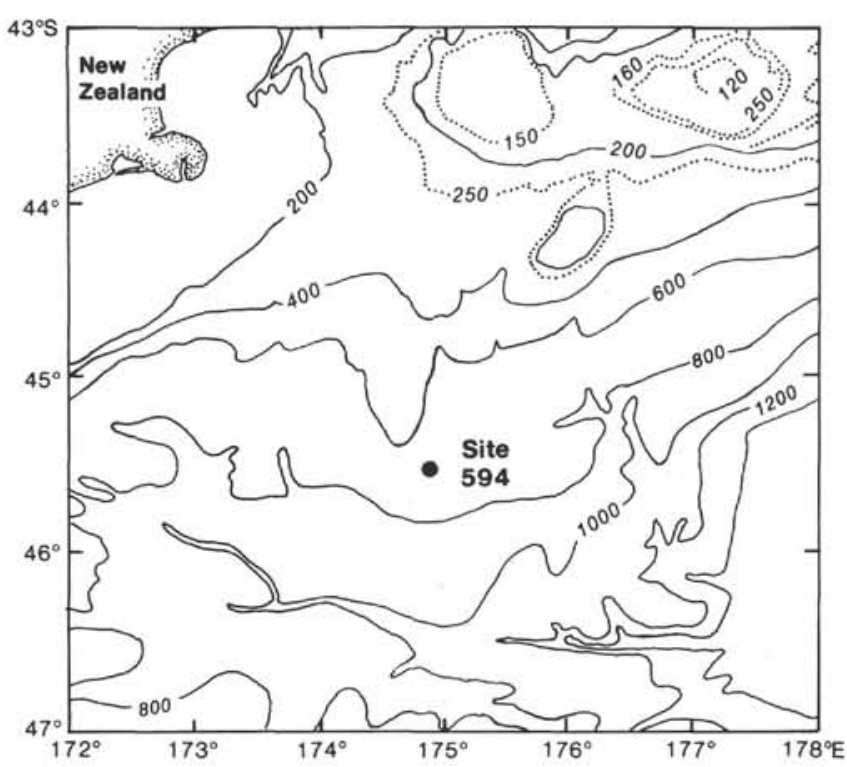

Figure 1. Location of DSDP Site 594.

\section{PREPARATION OF SAMPLES AND METHOD OF STUDY}

All samples used in this study were taken by scientists aboard the Glomar Challenger, Leg 90. A total of 85 samples were chemically processed to concentrate siliceous microfossils according to the procedure outlined by Ciesielski (1983).

Two strewn slides were prepared from the treated sample using $\mathrm{Hy}$ rax (n.d. $=1.71$ ) mounting medium and $22 \times 22 \mathrm{~mm}$ cover slips. In preparing slides an attempt was made to achieve uniform distribution of the sample material on the cover slips. Random-settling preparation 


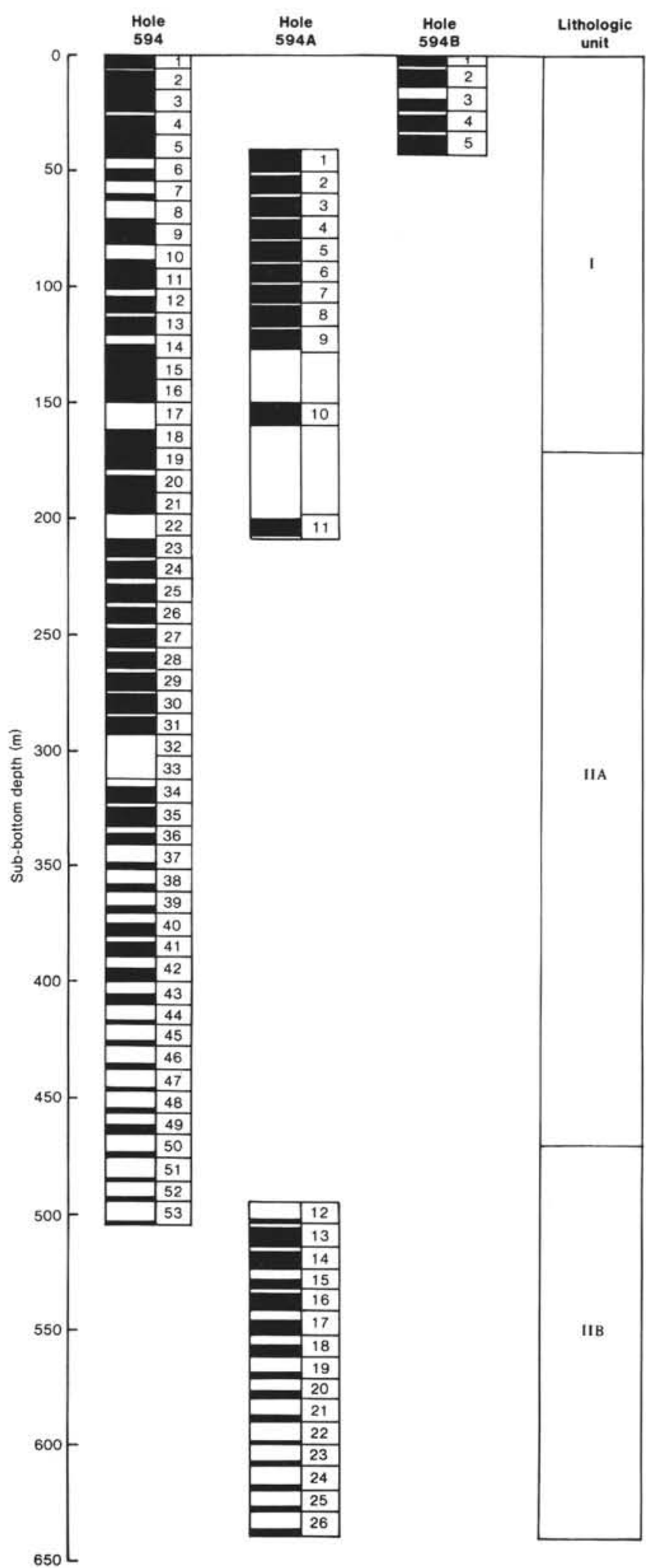

Figure 2. Lithologic columnar section of DSDP Site 594.

techniques were not used because of time restrictions on the preparation of this report.

All samples were sieved with a $45-\mu \mathrm{m}$ sieve and a strewn slide was prepared from the coarse-fraction residue. Sieved residues were prepared in order to eliminate the extremely high clay content of most
Miocene samples and to concentrate large diatoms and silicoflagellates of stratigraphic importance, such as Mesocena circulus, M. diodon, Hemidiscus cuneiformis, Coscinodiscus lewisianus, and others. For a more detailed discussion of the advantage of sieved-fraction examination the reader is referred to Gombos and Ciesielski (1983).

A Nikon Optiphot light microscope was used to determine the relative abundance of diatoms and silicoflagellates. Relative abundances are based on an examination of the entire whole-fraction slide (at $500 \times$ ). Identifications were checked at $1250 \times$. Relative abundances of species are designated as follows: $\mathrm{D}$, dominant, more than one specimen in every field of view; A, abundant, at least one specimen in every field of view; C, common, at least one specimen in every two to five fields of view; F, frequent, at least one specimen in every six to ten fields of view; S, sparse, several specimens observed on the entire slide; $\mathrm{R}$, rare, only one or two specimens observed on the entire slide.

Five traverses of sieved-fraction slides were made at $500 \times$ to check for rare species not present in whole-fraction slides. Species observed only in sieved-fraction slides are designated in Table 2 as $\mathrm{Vr}=$ very rare.

Estimates of the preservation of the diatom floras were made using the relative abundance of heavily silicified frustules versus less-silicified frustules. Five categories of preservation were noted: VP, very poor, sample with low diversity and abundance, generally dominated by sponge spicules and heavily silicified frustules, high fragmentation (e.g., Coscinodiscus marginatus and Actinocyclus ingens); P, poor, dominated by heavily silicified frustules but with less fragmentation and greater diversity; F, fair, dominated by heavily silicified frustules but with some moderately silicified frustules (e.g., Asteromphalus spp. and Brunia mirabilis) and rare, thinly silicified species, usually fragmented (e.g., Nitzschia spp.); M, moderate, greater diversity of heavily and moderately silicified diatoms (mostly unfragmented) and some well-preserved, thinly silicified species.

In general, only stratigraphically diagnostic diatoms are tabulated in Tables 1 and 2. The more important reference materials on the majority of the described taxa include McCollum (1975), Schrader (1973, 1976), Barron (1980a, b; 1981, 1983), and Ciesielski (1983). Silicoflagellate species listed in Tables 1 and 2 include only species of major stratigraphic importance.

\section{PALEOMAGNETIC CORRELATIONS AND EPOCH BOUNDARIES}

The paleomagnetic time scale utilized in this paper incorporates recent revisions of the middle Miocene portion of the time scale made by Kahn et al. (1984). These revisions are based on correlations of a long normal-polarity interval in DSDP Sites 563 and 558, which is associated with Zone NN9 (= Chron 11) and Zone N16, with marine Magnetic Anomaly 5. First-order magnetostratigraphic correlations of NN9 and N16 at these sites differ from previous second- and third-order correlations to Chron 9 by Berggren and van Couvering (1974), Ryan et al. (1974), and others. The reassignment of (Chron 11 $=$ Anomaly $5=$ Chron C5N) of Kahn et al. results in a 1.5-2.0 m.y. upward shift in the zonal boundaries of NN7/NN8 through NN10/NN11.

Correlation of Anomaly 5 with Chron 11 results in an absolute age assignment of 8.92-10.42 Ma for Chron 11 according to the Berggren et al. (in press) paleomagnetic time scale. Ages of Chrons 7 through 11 are also adjusted accordingly; however, traditional correlations of chrons and anomalies (Ryan et al. 1974; LaBrecque et al., 1977) younger than Chron 7 and older than Chron 14 appear correct and do not require adjustment (Berggren et al., in press).

Absolute ages of paleomagnetic boundaries shown in Figures 3-4 reflect the aforementioned revisions of Chrons 7 through 14 (Berggren et al., in press). Also indicated are the traditional chron boundaries with the revisions 
of Barron et al. (in press), the shortening of Chron 7 to include only Anomaly 4 (3 normal-polarity subchrons) and the lengthening of Chron 14 to include three additional normal-polarity subchrons below Anomaly 5A.

An alternate chron nomenclature system is now also in usage (Tauxe et al., 1983) and is also plotted in Figures 3-4 along with the more traditional nomenclature. This alternate nomenclature system labels successive chrons from the top of one numbered magnetic anomaly to the top of the next oldest anomaly; anomaly and chron numbers coincide.

\section{Epoch Boundaries}

The lower Miocene/middle Miocene boundary follows Ryan et al. (1974), with the upper part of the calcareous nannofossil NN4 (Helicopontosphaera ampliaperta) Zone of Martini (1971) within the upper part of paleomagnetic Chron $16(=16.0 \mathrm{Ma}=$ Chron C5B = Anomaly 5B). As defined, this boundary is closely approximated by the initial occurrence of Denticulopsis lauta in the North Pacific (Barron, 1980a). The initial D. lauta, which marks the base of the D. lauta Zone (NNPD4), occurs in upper Chron 16 at approximately $16.1 \mathrm{Ma}$ according to Barron et al.'s (in press) correlation to the Berggren et al. (in press) paleomagnetic time scale.

Kahn et al. (1984) have cited the base of the stratotype lower upper Miocene (Tortonian) as biostratigraphically within Zone NN8 and linked with the base of Anomaly 5. Their magnetochronology and revised magnetobiostratigraphy, therefore, places the middle/upper Miocene boundary (basal Tortonian) at approximately 10.4 Ma at the base of Chron 11 .

The Miocene/Pliocene boundary lies within the lower reversed-polarity subchron of the Gilbert Chron at approximately 5.2 Ma (Cita, 1975; Burckle, 1978; and others). The Pliocene/Quaternary boundary is placed above the Olduvai Normal Subchron (1.6 Ma) according to recent paleomagnetic data from the proposed boundary stratotype at Vrica, Italy (Tauxe et al., 1983).

\section{ZONATION}

Holes 594 and 594A contain a nearly continuous 16m.y. record of the uppermost lower Miocene through Quaternary. Middle upper Miocene to Quaternary diatom assemblages have a strong antarctic-subantarctic affinity which permits a biostratigraphic zonation of this interval utilizing well-established Neogene Southern Ocean diatom zones which have been correlated to magnetostratigraphy (McCollum, 1975; Weaver and Gombos, 1981; Ciesielski, 1983).

In the middle upper Miocene to Quaternary sediments of Samples 594-1-2, 4-5 cm through 594-50-2, 4-5 cm, 11 diatoms zones are recognized. These Neogene Southern Ocean diatom zones are those defined by Weaver and Gombos (1981) and amended by Ciesielski (1983). Definitions of these zones are provided in Figure 5.

Barron (in press, b) has presented a notation system for the Neogene Southern Ocean diatom (NSD) zonation of Weaver and Gombos (1981), designating Zones NSD 1 through NSD 16. This notation system is revised herein to include the additional Pliocene zones of Ciesi- elski (1983), resulting in 20 Neogene zones (NSD 1 through NSD 20, Fig. 5).

Samples 594-2-2, 4-5 cm through 594-43-1, 4-5 cm are representative of Zones NSD 7 through NSD 20. Below Sample 594-43-1, 4-5 cm, Neogene Southern Ocean diatom zones cannot be differentiated because of the absence of two species (Nitzschia grossepunctata and $N$. maleinterpretaria) used to define zonal boundaries of the base of the Nitzschia maleinterpretaria Zone (NSD 3 ). The only NSD zonal boundary identified in this lower portion of the section is the last occurrence of Coscinodiscus lewisianus, which defines the Coscinodiscus lewisianus Zone (NSD 4) boundary with the $N$. grossepunctata zone (NSD 5). Positions of the boundaries between the $N$. maleinterpretaria Zone (NSD 3 ) and C. lewisianus Zone (NSD 4) and the Nitzschia grossepunctata Zone (NSD 5) and $N$. denticuloides Zone (NSD 6), respectively, are inferred, using secondary datums present in Site 594 and the zonal type sections of Sites 266 and 278.

As previously noted by Barron (in press, b), the middle Miocene to lower upper Miocene diatom sequence of the Southern Ocean is very similar to that of the middle- to high-latitude North Pacific. Three North Pacific diatom zones are recognized between Sample 594-39-2, 4-5 $\mathrm{cm}$ and the base of Hole 594A; these include the Denticulopsis hustedtii-D. lauta Zone (NNPD 5), D. lauta Zone (NNPD 4), and Actinocyclus ingens Zone (NNPD 3). Table 2, later, reveals the relationship of NNPD and NSD zones in the upper lower Miocene to lower upper Miocene of Site 594. Further discussion of zonal occurrences and characteristics is presented in the following section.

\section{BIOSTRATIGRAPHY OF SITE 594}

\section{Pliocene to Quaternary (Table 1, Figs. 3, 5)}

Pliocene and Pleistocene diatoms of Hole 594 (Core 1 through Sample 594-20-2, 4-5 cm) and Hole 594A (Core 1 through Core 10 ) are generally characterized by fair to poor preservation and limited diversity. Throughout this entire sequence, antarctic-subantarctic diatoms predominate and are therefore zoned using the regional Southern Ocean diatom zonation of Ciesielski (1983). The occurrences of diatoms in each Pliocene-Pleistocene sample are recorded in Table 1, along with selected silicoflagellates and reworked diatoms and silicoflagellates. Figure 3 illustrates the depth in hole of major diatom, radiolarian, and foraminiferal datums and their correlation to paleomagnetic stratigraphy.

The upper $\sim 124 \mathrm{~m}$ of Holes 594 and 594A, through 594A-10-2, 4-5 cm, contain an apparently continuous sequence of the upper Pliocene-Quaternary. Detailed chronostratigraphic control is provided throughout this sequence by numerous biostratigraphic datums and by a single paleomagnetic reversal boundary (the Brunhes/ Matuyama boundary).

Paleomagnetic measurements were made at $50-\mathrm{cm}$ intervals for samples from the HPC sections of Holes 594 and 594A. Unfortunately, below Core 594-13 intensities were too low for results to be reliable. One paleomagnetic boundary was identified within Sample 594-11-5, 


\begin{tabular}{|c|c|c|}
\hline Zone & Notation & Zonal definitons \\
\hline Coscinodiscus lentiginosus & NSD 20 & \\
\hline C. elliptoporal & NSD 19 & Last Actinocyclus ingens \\
\hline Rhizosolenia barboil & & Last Rhizosolenia barboi \\
\hline $\begin{array}{l}\text { Nitzschia kerguelensis } \\
\text { C. kolbeil }\end{array}$ & NSD 18 & Last Coscinodiscus kolbei \\
\hline R. barboi & NSD 17 & Last $C$. vulnificus \\
\hline C. vulnificus & NSD 16 & Last Cosmiodiscus insignis \\
\hline Cosmiodiscus insignis & NSD 15 & Last Nitzschia weaveri \\
\hline N. weaveri & NSD 14 & Last $N$. interfrigidaria \\
\hline $\begin{array}{l}\text { N. interfridigaria/ } \\
\text { Coscinodiscus vulnificus }\end{array}$ & NSD 13 & First concurrent occurrence of \\
\hline N. interfrigidaria & NSD 12 & First $N$ weaveri \\
\hline N. praeintertrigidaria & NSD 11 & First $\mathrm{N}$ interfrigidaria \\
\hline N. angulata & NSD 10 & First $N$. angulata \\
\hline N. reinholdii & NSD 9 & Last abundance appearance datum of \\
\hline Denticulopsis hustedtii & NSD 8 & Denticulopsis hustedtii \\
\hline D. hustedtii/D. lauta & NSD 7 & Last abundance appearance datum of \\
\hline N. denticuloides & NSD 6 & N. denticuloides \\
\hline N. grossepunctata & NSD 5 & Last $N$. grossepunctata \\
\hline C. lewisianus & NSD 4 & Last $C$. lewisianus \\
\hline N. maleinterpretaria & NSD 3 & Last $N$. maleinterpretaria \\
\hline C. rhombicus & NSD 2 & Last $C$. rhombicus \\
\hline Rocella gelida & NSD 1 & Last Rossiella sp.A \\
\hline
\end{tabular}

Figure 5. The Neogene Southern Ocean diatom zonation of Weaver and Gombos (1981), as amended by Ciesielski (1983), with zonal definitions. The Neogene Southern Ocean diatom (NSD) notation is modified from Barron (in press, b) to include the Pliocene to Quaternary zonation of Ciesielski (1983).

$75-77 \mathrm{~cm}$; it was assumed to be the Brunhes/Matuyama Chronozone boundary (Barton and Bloemendal, this volume).

In spite of the great depth $(99 \mathrm{~m})$ of the Brunhes/Matuyama boundary $\left(730 \times 10^{3} \mathrm{yr}\right)$, its identification is confirmed by the shallower occurrences of several welldefined Brunhes datums. Among these is the last appearance of Actinocyclus ingens $\left(620 \times 10^{3}\right.$ yr. $)$ in Sample 594-9-5, 4-5 cm, marking the boundary between the overlying Coscinodiscus lentiginosus Zone (NSD 20, $0-620 \times 10^{3}$ yr.) and the C. elliptopora/Actinocyclus ingens Zone. Other important recognized datums of the Brunhes Chron include the last appearances of the radiolarian Stylatractus universus $\left(425 \times 10^{3} \mathrm{yr}\right.$.) in Section 594-7-2 and Hemidiscus karstenii $\left(195 \times 10^{3}\right.$ yr.) in Sample 594-3-5, 4-5 cm. Under the assumption of a constant Brunhes Chronozone sedimentation rate, the ages of the three aforementioned datums appear similar to previously published results.

The initial occurrence of the foraminifer Globorotalia truncatulinoides is in Sample 594-3,CC, immediately below the last occurrence of Hemidiscus karstenii, which is only slightly older than 200,000 yr. Even though the initial G. truncatulinoides approximates the Plio/Pleistocene boundary in lower latitudes, its first occurrence at this site is within the late Pleistocene, as in other subantarctic areas.
Rhizosolenia barboi and C. kolbei both last occur in Sample 594-15-2, 4-5 cm. The presence of these two species in the absence of C. vulnificus indicates the Coscinodiscus kolbei/Rhizosolenia barboi Zone (NSD 17, 2.22-1.89 Ma). Elsewhere in the subantarctic, the last appearance of $C$. kolbei $(1.89 \mathrm{Ma})$ occurs earlier than the last appearance of $R$. barboi $(1.5 \mathrm{Ma})$, thus defining the R. barboi/Nitzschia kerguelensis Zone (NSD 18, 1.89-1.58 Ma).

The joint last occurrences of $C$. kolbei and $R$. barboi and the absence of the $R$. barboi/N. kerguelensis Zone, however, is not thought to be conclusive evidence of a disconformity. This zone represents only $300,000 \mathrm{yr}$. and could be present in the $14.7-\mathrm{m}$ unsampled interval between Samples 594-15-2, 4-5 cm and 594-13-5, 4-5 cm (Fig. 3).

Samples 594-15-2, 4-5 cm through 594A-10-2, 4-5 cm contain three of the four upper Gauss Chronozone to lower Matuyama Chronozone diatom zones of Ciesielski (1983). Diatom zones identified within this interval include: the C. kolbei/R. barboi Zone (NSD 17, 2.22 $1.89 \mathrm{Ma}$ ) in Samples 594-15-2, 4-5 cm and 594-15-5, 4-5 cm; the Cosmiodiscus insignis Zone (NSD 15, 2.642.49 Ma) in Sample 594-16-2, 4-5 cm; and the $N$. weaveri Zone (NSD 14, 2.81-2.64 Ma) in Samples 594-16-5, 4-5 $\mathrm{cm}$ and 594A-10-2, 4-5 cm. The Coscinodiscus vulnificus Zone (NSD 16, 2.49-2.22 Ma) of the lower Matuya- 
Table 1. Stratigraphic distribution and relative abundances of selected diatom and silicoflagellate species in the Pliocene to Quaternary of Holes 594 and 594A.

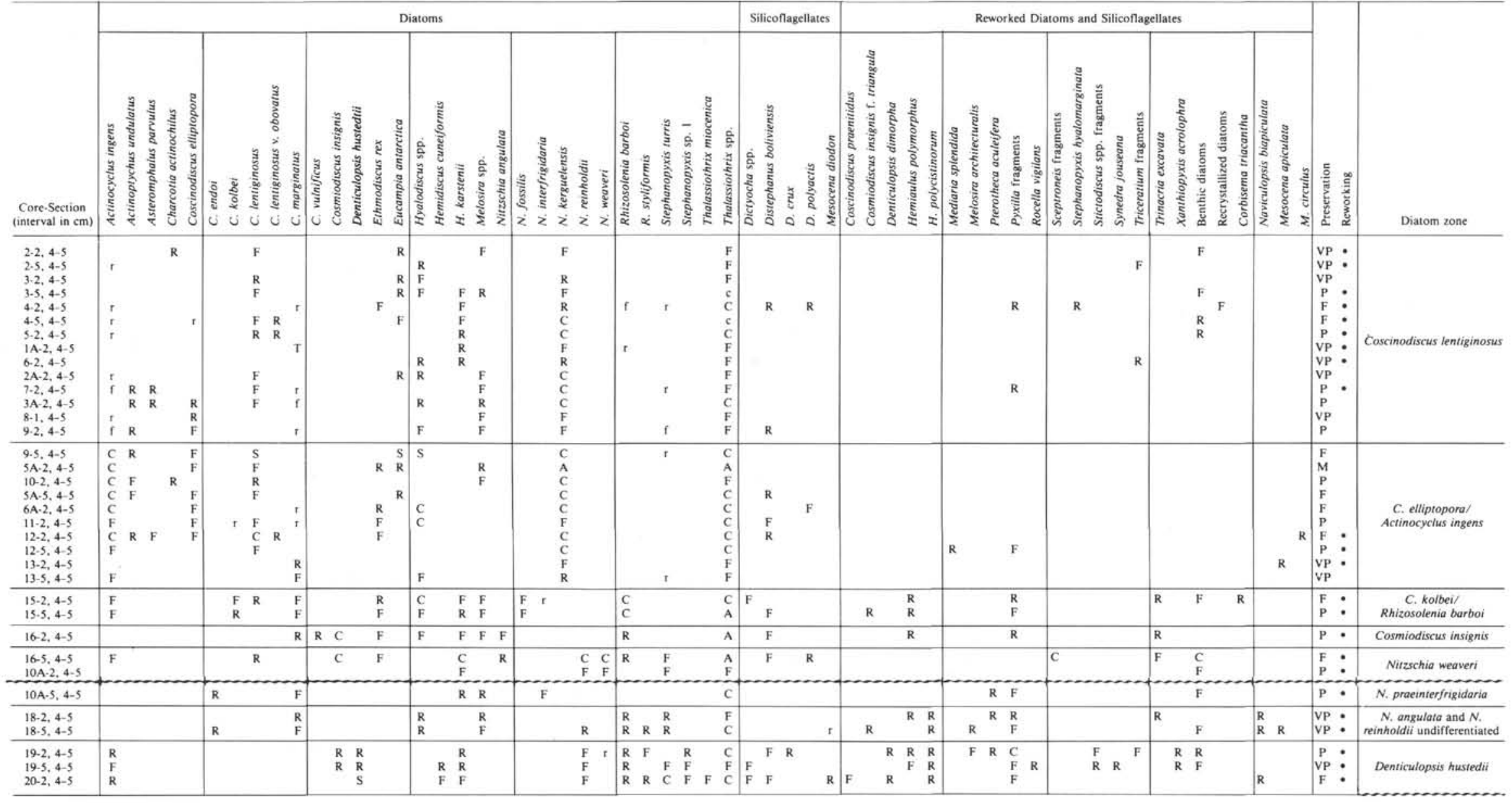

Note: R, rare; S, sparse;F. Irequent; C, common; A, abundant; lower-case abundance designators are interpreted as reworked occurrences; for explanation of abundances see Methods section. Reworked diatoms and silicoflagellates older than Pliocene listed separately. A after core num. ber denotes cores irom Hole $594 \mathrm{~A}$. 
ma Chronozone is unrepresented; however, it may be present in the 4.5-m interval between Samples 594-15-2, 4-5 cm and 594-15-5, 4-5 cm (Fig. 3).

A major disconformity spanning the upper Gilbert to lower Gauss chronozones occurs within Core 12 of Hole 594A, between Samples 594A-10-2, 4-5 cm and 594A$10-5,4-5 \mathrm{~cm}$. This hiatus separates sediments of the upper Gauss $N$. weaveri Zone above from the upper Gilbert $N$. praeinterfrigidaria Zone (NSD 11, 4.02-3.88 Ma) found below. Encompassed by the hiatus are the entire $N$. interfrigidaria Zone (NSD 12, 3.88-3.1 Ma) and the N. interfrigidaria/C. vulnificus Zone (NSD 13, 3.10$2.81 \mathrm{Ma})$.

Sediment immediately beneath the hiatus (Sample 594A-10-5, 4-5 cm) contains the sole occurrence of $N$. interfrigidaria and is assigned to the $N$. praeinterfrigidaria Zone (NSD 11, 4.02-3.88 Ma). The apparent hiatus thus encompasses the interval from approximately 3.9 to $2.8 \mathrm{Ma}$, thus eliminating most of the stratigraphic range of index species such as $C$. vulnificus, $N$. interfrigidaria, $N$. weaveri, and the acme of $C$. lentiginosus var. obovatus. Alternatively, the $1.1 \mathrm{~m}$.y. upper Gilbertlower Gauss Chronozone interval may be present in the 4.5-m unsampled interval between Samples 594A-10-2, 4-5 cm and 594A-10-5, 4-5 cm. This explanation would appear unlikely, given the high sedimentation rates above and below this level (see Site 594 site chapter, this volume).

Approximately $24 \mathrm{~m}$ of midd̄le Gilbert Chronozone sediment was identified in Samples 594A-10-5, 4-5 cm through $594-20-2,4-5 \mathrm{~cm}$. This sequence is bounded by the upper Gilbert-lower Gauss hiatus in Core 594A-10 and an upper Chron 5-lower Gilbert hiatus in Core 594-20. Samples 594A-10-5, 4-5 cm through 594-18-5, $4-5 \mathrm{~cm}$ are assigned to the $N$. angulata Zone (NSD 10, 4.2-4.02 Ma) and $N$. reinholdii Zone (NSD 9, 4.48-4.22 $\mathrm{Ma}$ ) as this interval is above the last occurrence of Denticulopsis hustedtii and below the initial $N$. interfrigidaria. These two zones are not differentiated because of the absence of $N$. angulata, apparently as a result of the very poor to poor preservation of this interval.

Sediment from the last occurrence of $D$. hustedtii (4.5 Ma; Ciesielski, 1983) in Sample 594-19-2, 4-5 cm through $594-20-2,4-5 \mathrm{~cm}$ is assigned to the lower Gilbert Chronozone portion of the Denticulopsis hustedtii Zone (NSD 8, 4.48-8.7 to 8.5 Ma). The last occurrence of the silicoflagellate Mesocena diodon (4.57 Ma; Ciesielski, 1983) occurs near the base of this interval (Sample 594-20-2, 4-5 cm), thus marking the top of the Mesocena diodon Zone. Based on previous paleomagnetic correlations of Ciesielski (1983), Core 594-19 and upper Core 594-20 represent only a portion of the reversed-polarity interval between the Sidufjall and Thvera subchronozones and a portion of the Thvera Subchronozone.

\section{Miocene (Tables 2 and 3, Figs. 4, 6, 7)}

Determining sediment ages of the Miocene sequence in Holes 594 and 594A is more difficult than in the Pliocene and Quaternary, where datums and diatom zones are correlated to magnetostratigraphy with high precision. In the southern mid to high latitudes, portions of the upper Miocene have been loosely correlated to paleomagnetic stratigraphy (Ciesielski, 1983), whereas the lower to middle Miocene zonal schemes have had no direct correlation to magnetostratigraphy. Unfortunately, paleomagnetic measurements of the Miocene section of Site 594 were too weak to provide a reliable magnetostratigraphy for direct correlation of Miocene Southern Ocean diatom zones.

Discussed in the following section are: (1) the occurrence of Miocene Southern Ocean diatom zones in Site 594, (2) a direct correlation of Miocene North Pacific diatom zones to Southern Ocean diatom zones, and (3) a correlation of the Miocene section at Site 594 to magnetostratigraphy.

\section{Miocene Southern Ocean Diatom Zones}

The Denticulopsis hustedtii Zone (NSD 8), as defined by McCollum (1975) and Weaver and Gombos (1981), brackets the Miocene/Pliocene boundary. This is true also in Hole 594, where the Miocene/Pliocene boundary appears to be a disconformity between Samples 594-20-2, 4-5 cm and 594-20-5, 4-5 cm (Fig. 4). Beneath this disconformity, the $D$. hustedtii Zone extends down to Sample 594-26-2, 4-5 cm.

The last occurrence of Denticulopsis lauta occurs in Sample 594-27-2, 4-5 cm, thus marking the boundary between the $D$. hustedtii Zone (NSD 8) and the underlying $D$. hustedtii/D. lauta Zone (NSD 7). The D. hustedtii/D. lauta Zone is a thick $(\sim 152 \mathrm{~m})$ sequence extending down-section through Sample 594-43-1, 4-5 cm. Preservation is moderate to fair and diversity relatively high throughout the upper $\sim 66 \mathrm{~m}$ of the zone; however, diversity declines significantly in the lower $86 \mathrm{~m}$, where preservation is consistently poor to very poor (Table 2 ).

Sample 594-44-1, 4-5 cm contains the last appearance datum of Nitzschia denticuloides, defining the top of the Nitzschia denticuloides Zone (Weaver and Gombos, 1981; NSD 6) and coinciding closely with the middle/upper Miocene boundary (Ciesielski, 1983). The base of the $N$. denticuloides Zone is not recognized in Site 594 because of the absence of the high-latitude species $N$. grossepunctata. The next NSD zonal datum encountered downcore is the last occurrence of Coscinodiscus lewisianus in Sample 594-52-2, 4-5 cm, marking the upper boundary of the Coscinodiscus lewisianus Zone (Schrader, 1976; Weaver and Gombos, 1981; NSD 4). The aforementioned datums indicate that the $N$. denticuloides Zone (NSD 6) and N. grossepunctata Zone (NSD 5) occur between Samples 594-44-1, 4-5 cm and 594-51-1, 4-5 cm, although the datum defining the boundary between the zones (LAD N. grossepunctata) is unrecognized.

In the absence of $N$. grossepunctata, the boundary between the $N$. denticuloides Zone and $N$. grossepunctata Zone is inferred to be coincident with the first occurrence of $N$. denticuloides, as noted by Weaver and Gombos (1981). In Site 594, the first $N$. denticuloides occurs in Sample 594-50-2, 4-5 cm; therefore, the $N$. denticuloides Zone ranges from Sample 594-44-1, 4-5 cm through 594-50-2, 4-5 cm. The $N$. grossepunctata zonal equivalent is constrained to a single sample (594-51-1, 
4-5 $\mathrm{cm}$ ) by the last occurrence of $C$. lewisianus (594-52-2, 4-5 $\mathrm{cm}$ ), which defines the top of the $C$. lewisianus Zone (Schrader, 1976).

The defined base of the $C$. lewisianus Zone (the last N. maleinterpretaria, Weaver and Gombos, 1981) is unrecognized in Site 594; however, its base is correlated to this site by the relationship of the $N$. maleinterpretaria datum in Sites 266 and 278 to the first occurrence of $D$. lauta at all three sites. In Site 278 , the first $D$. lauta is coincident with the last $N$. maleinterpretaria in Sample $278-20-5,80-81 \mathrm{~cm}$ (Schrader, 1976) and is used here as a substitute marker for the base of the $C$. lewisianus Zone. Thus, the base of the zone in Hole 594A is inferred to be at the first occurrence of D. lauta in Sample 594A-17-5, 4-5 cm (Table 2).

The interval from Sample 594A-18-2, 4-5 cm through Sample 594A-21-2, 4-5 cm, the lowermost diatom-bearing sample, appears to represent only a portion of the N. maleinterpretaria Zone (Weaver and Gombos, 1981; NSD 3). Several datums occur within the $N$. maleinterpretaria zonal equivalent at Site 278 ; these include the first occurrence of the genus Denticulopsis, C. lewisianus, and Brunia mirabilis. The absence of $C$. rhombicus in the lowermost diatom-bearing sample (594A-21-2, 4-5 $\mathrm{cm}$ ) further supports a position within the $\mathrm{N}$. $\mathrm{ma}$ leinterpretaria Zone, because the last occurrence of this species defines its base. Coscinodiscus rhombicus occurs at a similar latitude in the Atlantic (Site 513, $47^{\circ} 35^{\prime} \mathrm{S}$ ) and should be present at Site 594 if the stratigraphic horizon were reached.

Sample 594A-23-2, 4-5 cm through the base of Hole 594A (594A-26, CC) appears to be correlative to the $N$. maleinterpretaria Zone, even though the interval is barren of diatoms. This inference is based on Martini's (this volume) discovery of the calcareous nannofossil Sphenolithus heteromorphus in Sample 594A-26,CC. At Site 266 , the first occurrence of $S$. heteromorphus occurs within the middle portion of the $N$. maleinterpretaria Zone (Sample 266-17-1, Weaver and Gombos, 1981). On this basis the interval between Sample 594-18A-2, 4-5 $\mathrm{cm}$ through $594 \mathrm{~A}-26, \mathrm{CC}$ is assigned to the $N$. maleinterpretaria Zone.

The base of Hole 549A is within calcareous nannofossil Zone NN5 (Martini, this volume); therefore, according to Ryan et al. (1974) and Berggren et al. (in press), the base of Hole 594A would be lowermost middle Miocene. Jenkins and Srinivasan (this volume) favor placement of the early/middle Miocene boundary between Samples 594A-20,CC and 594A-21,CC. Diatoms cannot be used to reconcile this discrepancy because of the effects of dissolution on age-diagnostic taxa in the lower portion of Hole 594A.

\section{Correlation of Site 594 to Miocene North Pacific Diatom Zones}

Uppermost lower Miocene through lower upper Miocene North Pacific diatom Zones NNPD 3 to NNPD 5 are recognized in Holes 594 and 594A and are correlated directly to Neogene Southern Ocean diatom Zones NSD 3 through NSD 7 (Table 2). The Neogene North Pacific diatom zones recognized herein and the respective authors of these zones are: Actinocyclus ingens Zone (NNPD 3, Barron, 1980a), Denticulopsis lauta zone (NNPD 4; Koizumi, 1973; Barron, 1980a; amended Barron and Keller, 1983), and the $D$. hustedtii-D. lauta Zone (NNPD 5; Koizumi, 1973; amended by Barron, 1980a, and Barron and Keller, 1983).

The Neogene North Pacific $D$. hustedtii- $D$. lauta Zone (NNPD 5) is defined as the interval from the evolutionary transition of $D$. hyalina to $D$. hustedtii (recognized by the first consistent dominance of $D$. hustedtii over $D$. lauta; Barron et al., in press) to the last occurrence of D. dimorpha. In Site 594 both of these datums are recognized in Samples 594A-14-2, 4-5 cm and 594-29-2, $4-5 \mathrm{~cm}$, respectively. The $D$. hustedtii-D. lauta zone (NNPD 5) of the North Pacific, therefore, is inclusive of most of the D. hustedtii/D. lauta Zone (NSD 7), $N$. denticuloides Zone (NSD 6), N. grossepunctata Zone (NSD 5), and upper Coscinodiscus lewisianus Zone (NSD 4) (Table 2).

Barron (1980a) defined four subzones of the $D . h u$ stedtii-D. lauta zone which can also be correlated to $\mathrm{Ne}-$ ogene Southern Ocean diatom zones. Subzone d, the youngest of these zones, is the interval from the last to the first occurrence of $D$. dimorpha. In Site 594, Subzone d extends from Sample 594-29-2, 4-5 cm to 594-47-1, 4-5 $\mathrm{cm}$. The subzone contains the last occurrences of Mediaria splendida and $D$. praedimorpha, as was noted previously in the North Pacific by Barron (in press, b). Correlation of Subzone d to NSD zones in Site 594 reveals that it brackets the boundary between the $D$. $h u$ stedtii/D. lauta Zone (NSD 7) and the $N$. denticuloides Zone (NSD 6). This relationship of the NSD 7/NSD 6 boundary to Subzone d is the same at South Atlantic Site 512 (Ciesielski, 1983) and appears to be isochronous throughout the Southern Ocean.

The first occurrence of $D$. praedimorpha in Sample 594-49-2, 4-5 cm marks the base of Barron's (1980a) Subzone b. The base of Subzone c, the first occurrence of Rhizosolenia barboi, cannot be used to identify to Subzone b/c boundary because $R$. barboi has its first occurrence earlier in the southern high latitudes than in the North Pacific (McCollum, 1975; Schrader, 1976; Gombos and Ciesielski, 1983; and others). Even though $R$. barboi occurs sporadically in the basal portion of the Site 594 section, its first consistent occurrence is coincident with the first occurrence of $D$. praedimorpha and the base of Subzone b. Thus the first consistent occurrence of $R$. barboi at Site 594 (base of Subzone b) is slightly older than its North Pacific first occurrence (top of Subzone b).

Subzones $\mathrm{c}$ and $\mathrm{b}$ of the $D$. hustedtii- $D$. lauta Zone (NNPD 5) are confined to only two samples, Samples $594-48-2,4-5 \mathrm{~cm}$ and $594-49-2,4-5 \mathrm{~cm}$. The poor stratigraphic representation of these subzones, as compared to many North Pacific sites, may be the consequence of low sedimentation rates, the presence of an undetected disconformity, or different ranges of species to define the top of Subzone c (FAD D. dimorpha) and the base of Subzone b (FAD D. praedimorpha). Both Subzones b 


\section{P. F. CIESIELSKI}

Table 2. Stratigraphic distribution and relative abundances of selected diatom and silicoflagellate species in the Miocene of Holes 594 and 594A.

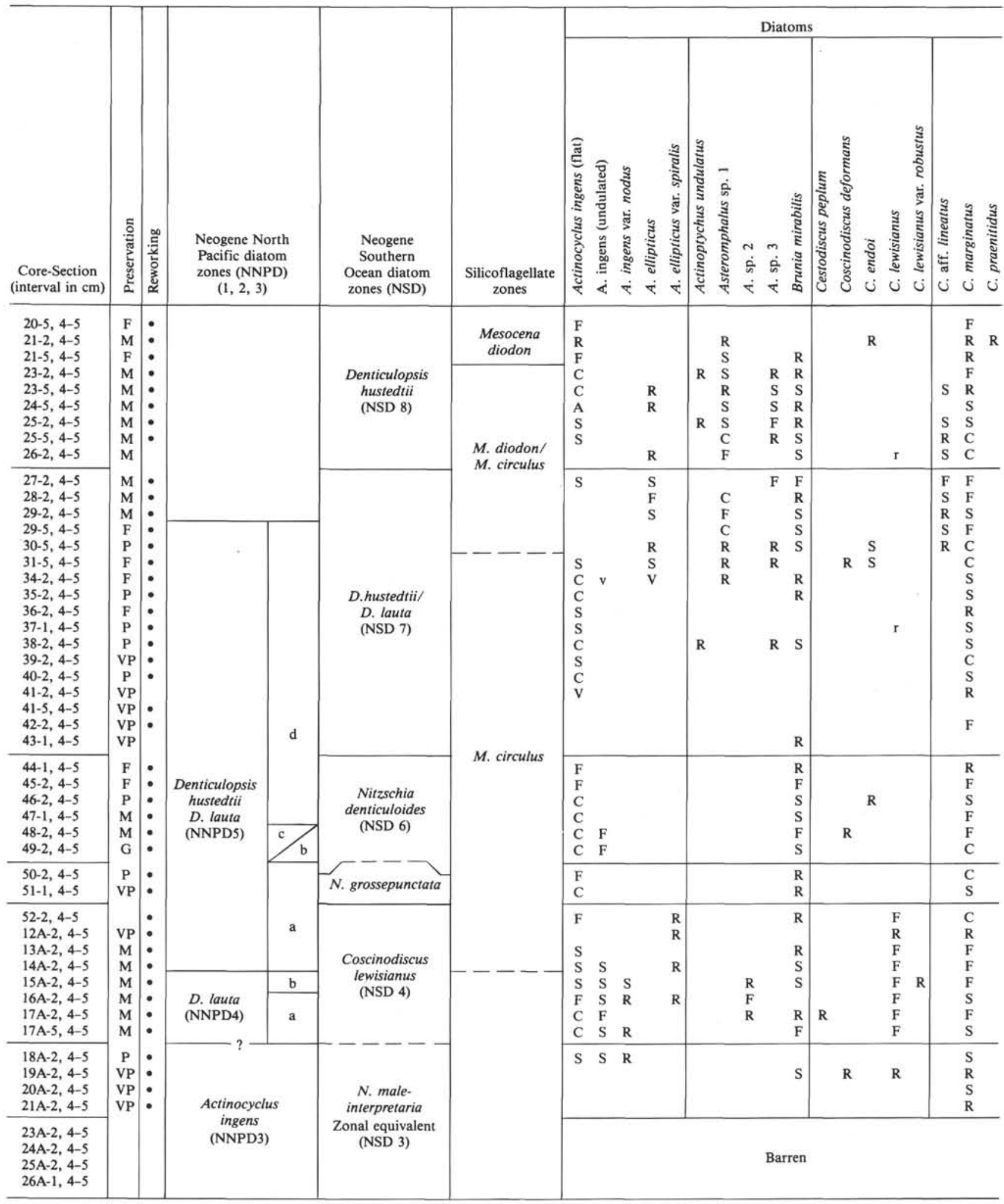

Note: V, very rare; R, rare; S, sparse; F, frequent; C, common; A, abundant; D, dominant; lower-case abundance designators are interpreted as reworked occurrences; for explanation of abundances see Methods section. Reworked diatoms and silicoflagellates older than middle Miocene listed separately. A after core number denotes cores from Hole 594A. 


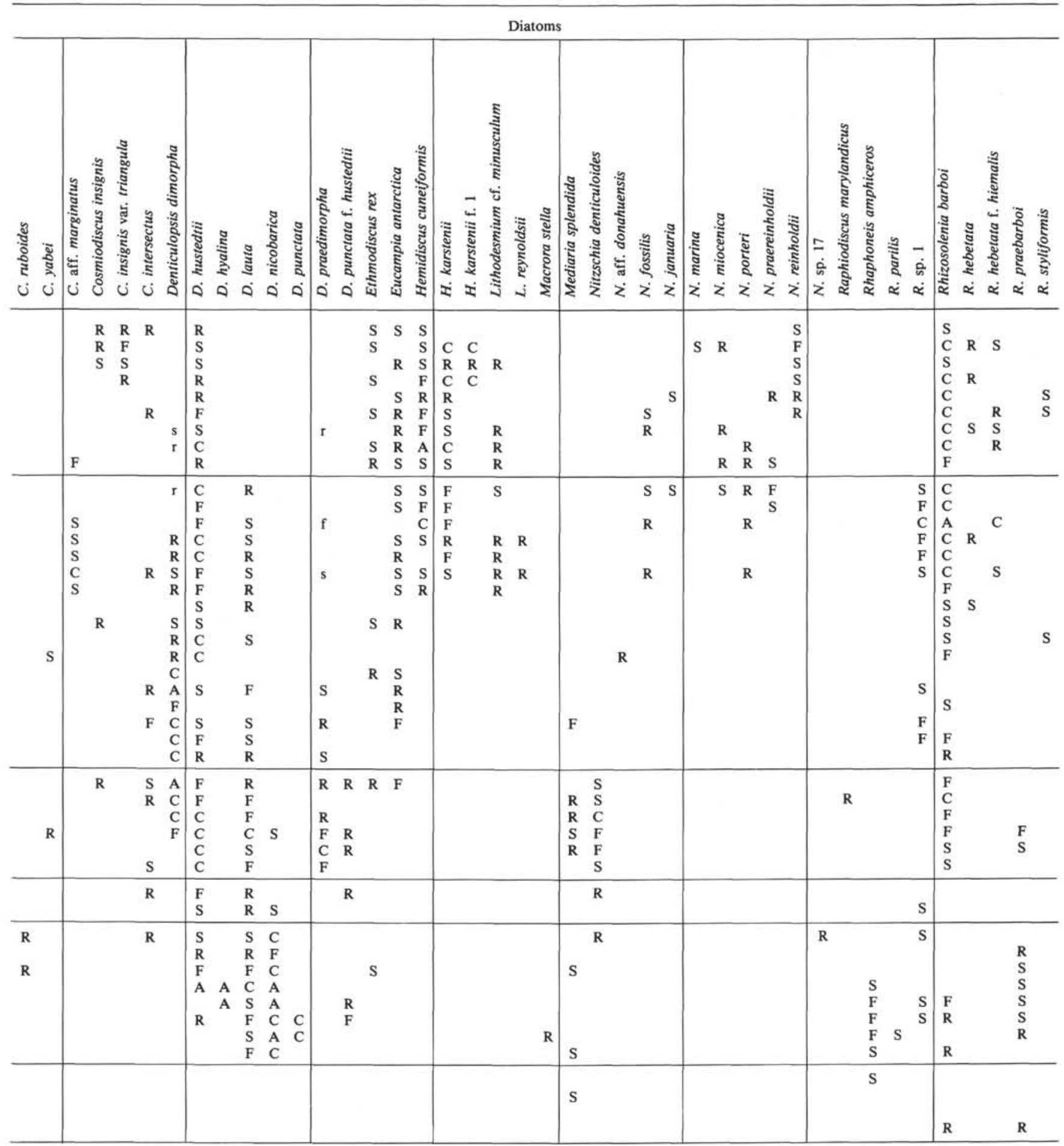

Barren

and $\mathrm{c}$ of Barron (1980a) are shown to correlate to the lower $N$. denticuloides Zone (NSD 6) of the Southern Ocean.

The bottom of Subzone a, the basal subzone of NNPD 5, occurs in Sample 594A-14-2, 4-5 cm, where the evo- lutionary transition of $D$. hyalina to $D$. hustedtii is recognized by the first consistent dominance of $D$. hustedtii over $D$. hyalina. Subzone a occurs in Samples 594-50-2, 4-5 cm through 594A-14-2, 4-5 cm, encompassing the lowermost $N$. denticuloides Zone (NSD 6), 


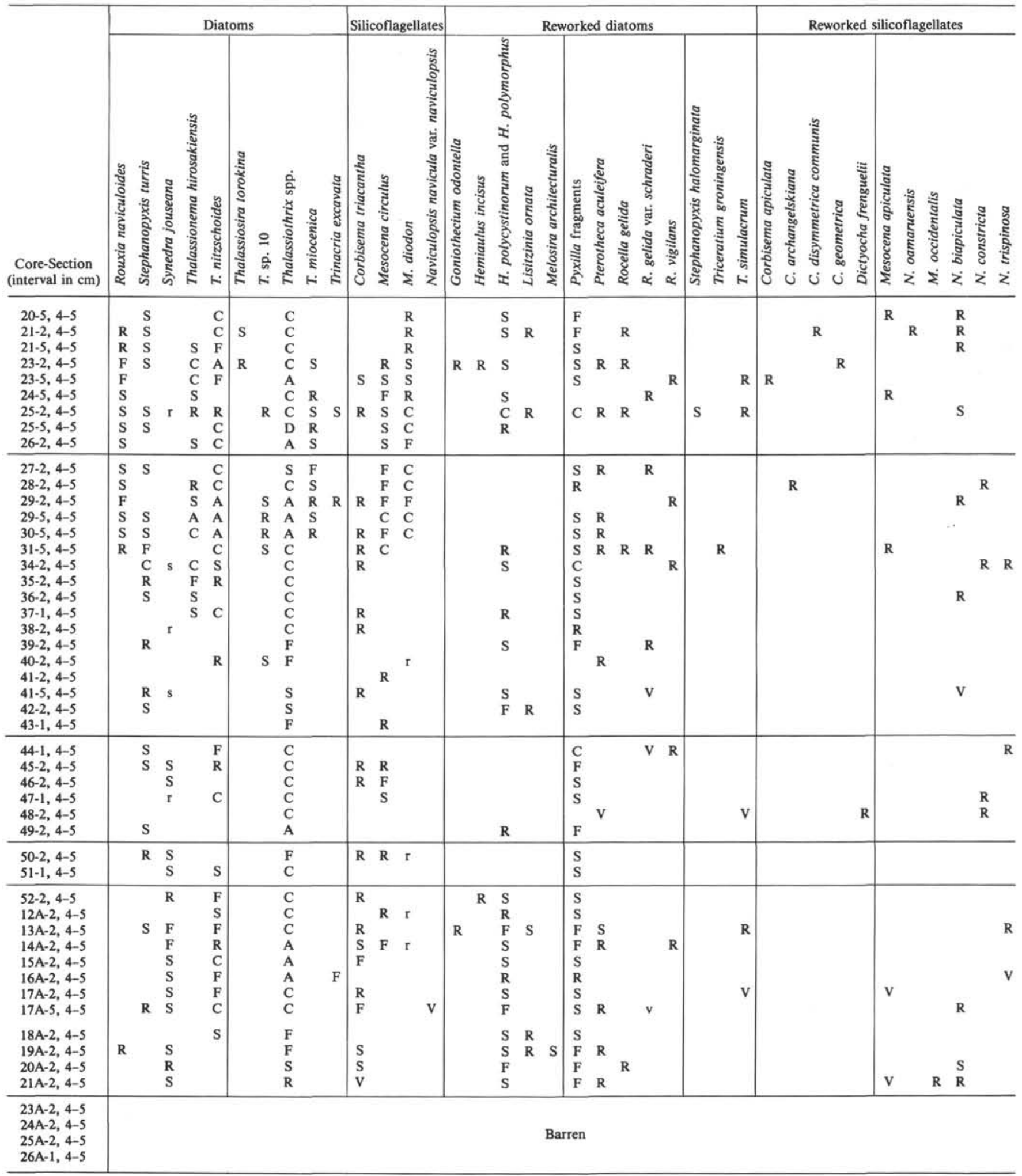

$N$. grossepunctata Zone (NSD 5), and upper C. lewisianus Zone (NSD 4). At Site 594, C. lewisianus has its last occurrence in the upper part of Subzone a, similar to its position in the North Pacific (Barron, in press, b).

The North Pacific D. lauta Zone (NNPD 4, Koizumi, 1973; Barron, 1980a; Barron and Keller, 1983) is recog- nized in Sample 594A-15-2, 4-5 cm through the lowest occurrence of D. lauta in Sample 594A-17-5, 4-5 cm. The first occurrence of $D$. hyalina, basal datum of Barron's (1980a) Subzone b, occurs in Sample 594A-15-2, $4-5 \mathrm{~cm}$, the sole sample representing this subzone. Samples 594A-16-2, 4-5 cm through 594A-17-5, 4-5 cm rep- 
Table 3. Ages of important stratigraphic diatom, radiolarian, silicoflagellate, and calcareous nannofossil datum levels in the Miocene of DSDP Holes 594 and 594A.

\begin{tabular}{|c|c|c|c|c|c|}
\hline $\begin{array}{l}\text { Core-Section } \\
\text { (level in } \mathrm{cm} \text { ) }\end{array}$ & & & Datum & $\begin{array}{l}\text { Age (Ma) } \\
\text { (reference in } \\
\text { parentheses) }\end{array}$ & $\begin{array}{l}\text { Dating technique or } \\
\text { direct paleomagnetic } \\
\text { correlation }\end{array}$ \\
\hline $21-5,4-5$ & & LAD & Brunia mirabilis & $5.6(5)$ & Within Chron 5 \\
\hline \multirow[t]{4}{*}{$23-2,4-5$} & 1. & FAD & Cosmiodiscus insignis var. triangula & $6.4^{\circ}(5)$ & Within $(+)$ of Chron 6 \\
\hline & 2. & LAD & Mesocena circulus (S) & $6.4-5.9(5)$ & upper Chron 6 \\
\hline & 3. & LAD & Thalassiothrix miocenica & - & \\
\hline & 4. 1 & FAD & Thalassiosira torokina & $6.4-5.9(5)$ & Upper $(-)$ of Chron 6 \\
\hline $23-5,4-5$ & & LAD & Actinocyclus ellipticus & - & \\
\hline $23, \mathrm{CC}$ & & LAD & Discoaster quinqueramus (N) & $5.5^{*}(1)$ & Top of $(-)$, Chron 5 \\
\hline $24-5,4-5$ & & FAD & Nitzschia reinholdii & $5.6(5)$ & Base of first $(+)$, Chron 5 \\
\hline $25-5,4-5$ & & LAD & N. porteri & $6.7^{\bullet}(1)$ & upper Chron 7 \\
\hline \multirow[t]{2}{*}{$26-2,4-5$} & $1 .+$ & LAD & Diartus hughesi (R) & $\begin{array}{r}+8.5(7) \\
7.0(6)\end{array}$ & $\begin{array}{l}\text { mid to lower Chron } 10 \text { (7), } \\
\text { lower Chron } 7(6)\end{array}$ \\
\hline & 2. & LAD & Coscinodiscus aff. marginatus & - & - \\
\hline $26-5,3-4$ & & FAD & Discoaster quinqueramus $(\mathrm{N})$ & $7.3^{\circ}(4)$ & 2nd (-), Chron 7 \\
\hline $27-2,3-4$ & & FAD & Stichocorys peregrina $(\mathrm{R})$ & $6.4(12)$ & - \\
\hline \multirow[t]{3}{*}{$27-2,4-5$} & 1. 1 & LAD & Denticulopsis lauta & $\begin{array}{l}8.5-8.7(5) \\
+9.5(9)\end{array}$ & $\begin{array}{l}\text { lower Chron } 10 \\
\text { K-Ar date }\end{array}$ \\
\hline & 2. & LAD & Rhaphoneis sp. 1 & - & - \\
\hline & 3. + & FAD & Nitzschia miocenica & $6.8^{*}(1)$ & upper Chron 7 \\
\hline $28-2,4-5$ & & FAD & N. praereinholdii & - & - \\
\hline $28-5,4-5$ & & LAD & Discoaster hamatus $(\mathrm{N})$ & $8.8^{\circ}(3)$ & 2nd $(+)$, Chron 10 \\
\hline $29-2,4-5$ & & LAD & Thalassiosira sp. 10 & 8.7 (7) & $40 \mathrm{Ar} / 3{ }^{39} \mathrm{Ar}$ date \\
\hline \multirow[t]{4}{*}{$29-5,4-5$} & 1. & FAD & Thalassiothrix miocenica & $8.7(7)$ & $40 \mathrm{Ar} /{ }^{39} \mathrm{Ar}$ date \\
\hline & 2. & LAD & Denticulopsis dimorpha & & \\
\hline & & & (temperate) & $8.6(8)$ & \\
\hline & & & (subantarctic) & $8.7(7)$ & \\
\hline $29, \mathrm{CC}$ & +1 & FAD & Discoaster hamatus (N) & $10.0(8)$ & \\
\hline $30-5,4-5$ & & First c & onsistent Mesocena diodon(s) & - & \\
\hline $31-2,3-4$ & & LAD & Cyrtocapsella japonica (R) & $8.7^{*}(7,6)$ & $\begin{array}{l}\text { Uppermost Chron } 11 \text { and } \\
{ }_{40} \mathrm{Ar} /{ }^{39} \mathrm{Ar} \text { date }\end{array}$ \\
\hline \multirow[t]{3}{*}{$31-5,3-4$} & 1. & FAD & Diartus hughesi (R) & $9.0^{*}(1)$ & Uppermost Chron 11 \\
\hline & 2. & FAD & Stylatractus universus (R) & 8.7 & $40 \mathrm{Ar} / 39 \mathrm{Ar}$ date \\
\hline & 3. & FAD & Didymocyrtis antepenultima (R) & $9.0^{\circ}(1)$ & Uppermost Chron 11 \\
\hline \multirow[t]{3}{*}{$31-5,4-5$} & 4. & FAD & Hemidiscus karstenii & $8.7(7)$ & $40 \mathrm{Ar} / 39 \mathrm{Ar}$ date \\
\hline & 5. & FAD & Nitzschia porteri & - & \\
\hline & 6. & FAD & N. fossilis & - & \\
\hline \multirow[t]{6}{*}{$34-2,4-5$} & 1. & FAD & Coscinodiscus aff. marginatus & $8.7(7)$ & ${ }^{40} \mathrm{Ar} /{ }^{39} \mathrm{Ar}$ date \\
\hline & 2. & FAD & Actinocyclus ellipticus & - & \\
\hline & 3. & FAD & Lithodesmium $\mathrm{cf}$. minusculum & - & \\
\hline & 4. & FAD & Asteromphalus sp. 1 & $8.7(7)$ & ${ }^{40} \mathrm{Ar} /{ }^{39} \mathrm{Ar}$ date \\
\hline & 5. 1 & FAD & Hemidiscus cuneiformis & $8.7(7)$ & $40 \mathrm{Ar} / 39^{\mathrm{Ar}}$ date \\
\hline & & & & $+11.2(4)$ & middle Chron 12 \\
\hline $39-2,4-5$ & & Last ce & mmon Denticulopsis dimorpha & - & \\
\hline $42-3,3-4$ & +1 & FAD & Discoaster kugleri $(\mathrm{N})$ & $11.8(8)$ & \\
\hline \multirow[t]{2}{*}{$44-1,4-5$} & + & LAD & Nitzschia denticuloides (dissolutional) & - & \\
\hline & & LAD & $\begin{array}{l}\text { Denticulopsis punctata } \\
\text { f. hustedtii }\end{array}$ & $10.7^{\bullet}(8)$ & Uppermost chron 12 \\
\hline \multirow[t]{2}{*}{$47-1,4-5$} & + & FAD & D. dimorpha (temperate) & $8.9(8)$ & \\
\hline & & LAD & D. nicobaria (isolated) & - & \\
\hline $49-2,4-5$ & +1 & FAD & D. praedimorpha (temperate) & $12.9(8)$ & \\
\hline $51-1,4-5$ & & Last cr & nsistent $D$, nicobaria & $12.6(8)$ & \\
\hline \multirow[t]{3}{*}{$52-2,4-5$} & & LAD & Conscinodiscus lewisianus & $12.9(8)$ & \\
\hline & & FAD & Nitzschia denticuloides & - & \\
\hline & 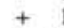 & LAD & Actinocyclus ellipticus spiralis & $\sim 11.0-10.8(11)$ & \\
\hline \multirow[t]{3}{*}{$14 \mathrm{~A}-2,4-5$} & $1 .+$ & LAD & Denticulopsis hyalina (temperate) & 15.0 & \\
\hline & 2. & LAD & Raphoneis amphiceros & - & \\
\hline & 3. & LAD & Actinocyclus ingens (undulated) & - & \\
\hline \multirow[t]{3}{*}{$14 A-5,4-5$} & & First c & mmon Denticulopsis hustedtii & & \\
\hline & & & (main range, tropics) & $13.9(11)$ & \\
\hline & & & & $14.0(9)$ & K-Ar date \\
\hline $15 \mathrm{~A}-2,4-5$ & 1. & LAD & Actinocyclus ingens var. nodus & - & \\
\hline & $2 .+1$ & FAD & Denticulopsis hyalina & $15.0(8)$ & \\
\hline $15 \mathrm{~A}, \mathrm{CC}$ & & LAD & Sphenolithus heteromorphus (N) & $14.0(8)$ & \\
\hline $16 \mathrm{~A}-2,4-5$ & 1. & FAD & Denticulopsis punctata f. hustedtii & $13.7(11)$ & \\
\hline & 2. & LAD & D. punctata & - & \\
\hline & 3. & FAD & D. hustedtii (isolated-tropics) & $14.2(11)$ & \\
\hline & 4. & FAD & Actinocyclus ellipticus var. spiralis & 14.2 to 14.1 (11) & \\
\hline $17 A-2,4-5$ & & FAD & Denticulopsis punctata & - & \\
\hline $17 \mathrm{~A}-5,4-5$ & & FAD & D. spp. (dissolutional) & - & \\
\hline $18 \mathrm{~A}-2,4-5$ & 1. & FAD & Raphoneis amphiceros & - & \\
\hline & 2. & FAD & R. parilis & - & \\
\hline & 3. & FAD & Actinocyclus ingens (dissolutional?) & $15.5(11)$ & \\
\hline
\end{tabular}

Note: Reference key is as follows: (1) Burckle, 1978; (2) Burckle, pers. comm. to Barron, in press, b; (3) Burckle et al., 1982; (4) Barron et al., in press; (5) Ciesielski, 1983; (6) Johnson and Wick, 1982; (7) based on position relative to ${ }^{40} \mathrm{Ar} /{ }^{39} \mathrm{Ar}$ date of $8.7+0.2 \mathrm{~m}$.y. from DSDP Hole 513A (Ciesielski, 1983); (8) Barron et al., in press, b; (9) Koizumi, 1977; (10) Burckle, pers. comm. to Barron, 1978; (11) Barron, in press, a; age extrapolated from Barron, in press, b. Other symbols: * Direct paleomagnetic correlation. + Datum at left not considered reliable because of preservational problems or apparent diachrony relative to the lower latitudes. A after core number denotes cores from Hole 594A. N = calcareous nannoplankton; $\mathrm{R}=$ radiolarian; $\mathrm{S}=$ silicoflagellate. In right-hand column, $(+)=$ normal polarity; $(-)=$ reversed polarity. 
resent Barron's (1980a) Subzone a of the D. lauta Zone (NNPD 4). The first occurrences of $D$. hustedtii, D. hyalina, D. punctata, and D. punctata var. hustedtii all fall within the D. lauta Zone. The portion of the D. lauta Zone (NNPD 4) represented here falls within the lower C. lewisianus Zone (NSD 4).

Samples 594A-18-2, 4-5 cm down to the basal barren zone of the hole beginning in Sample 594A-23-2, 4-5 cm are characterized by poor to very poor preservation and cannot be correlated with North Pacific diatom zones. Dissolution within this interval may have removed the lowermost occurrences of several diagnostic species, including the $A$. ingens group, Brunia mirabilis, D. lauta, and $D$. nicobarica. Dissolution is almost certainly responsible for the joint first occurrences of $D$. lauta and D. nicobarica in Sample 594A-17-5, 4-5 cm, because the first occurrence of $D$. nicobarica has been noted before the earliest $D$. lauta in the Southern Ocean (McCollum, 1975; Schrader, 1976) and throughout the low- to highlatitude Pacific (Barron, 1981, 1983; Schrader, 1976).

Samples 594A-18-5, 4-5 cm through the base of the hole (594A-26-1, 4-5 cm) probably fall within the lower D. lauta Zone (NNPD 4) and upper A. ingens Zone (NNPD 3). This conjecture is based on the placement of the early/middle Miocene boundary within this interval by Leg 90 paleontologists (Site 594 summary, this volume) and the paleomagnetic correlations (to follow herein) of microfossil datums in the lower part of Hole 594A. This interpretation would also agree with the correlation of the base of the $D$. lauta zone to approximately the early/middle Miocene boundary (Barron, 1980a; Barron and Keller, 1983).

\section{CORRELATION OF THE MIOCENE OF SITE 594 TO PALEOMAGNETIC STRATIGRAPHY}

Paleomagnetic studies of the HPC cores from the Miocene of Site 594 were unsuccessful in providing a magnetostratigraphy of the section because of low magnetic intensities (Barton and Bloemendal, this volume). The Miocene of Site 594 is here correlated to magnetostratigraphy generally, using microfossil datums which have been correlated directly or indirectly to magnetostratigraphy in middle- to lower-latitude sections. In the subantarctic and Antarctic, only a few diatom datums have been correlated to magnetostratigraphy (Ciesielski, 1983). These few correlations are not highly reliable because they are based on core sections bracketed by disconformities, making interpretations of the paleomagnetic record somewhat ambiguous.

A further complication of age interpretations at this site is the fact that the site lies just south of the Subtropical Convergence within the northern subantarctic zone. Temporal fluctuations of the Subtropical Convergence have resulted in a mixture of antarctic-subantarctic and temperate assemblages. Water mass migrations over the site have clearly resulted in microfossil datums which are diachronous with lower latitudes (Figs. 6 and 7, Table 3). In addition, dissolution may also have influenced the position of some datums.

Major foraminiferal, diatom, radiolarian, and silicoflagellate datums in the Miocene of Site 594 are illus- trated in Figure 4. The absolute ages of many of these datums are given in Table 3 along with the source of the age information, the bulk of which are studies of lowto middle-latitude sequences.

An age versus depth diagram was constructed (Fig. 7) for datums listed in Table 3 to assist in determining those Miocene datums that are diachronous. Those datums considered unreliable because of apparent diachrony (greater than 0.5 m.y.) are identified by the symbol " + " preceding the datum designation in Table 3. Datums which appear to be significantly younger at Site 594 than their recorded occurrence elsewhere include the FAD and LAD of Denticulopsis hyalina, FAD of $D$. praedimorpha, LAD of D. lauta, FAD of Hemidiscus cuneiformis, FAD of Discoaster kugleri, LAD of Diartus hughesi, and FAD of Discoaster hamatus. Datums significantly older than their recorded occurrence elsewhere are the FAD of Denticulopsis dimorpha and the LAD of Actinocyclus ellipticus spiralis.

Reference to Figure 4 reveals that the Miocene of Site 594 represents upper Chronozone 16 through Chron 5. Cores 594-24 through 594-41 are difficult to correlate to magnetic stratigraphy because of problems of diachrony, dissolution, and a lack of reliable datums in much of this section. An exception to this generalization is found between Cores 594-28 and 594-34, where a number of datums occur in the same succession as at southwest Atlantic Site 513 (Fig. 6). At both sites these datums occur in close proximity to a radiometrically dated ash layer which is $8.7 \pm 0.2 \mathrm{Ma}$. Cores $28-34$ can be confidently considered to be approximately 9.0 to $8.5 \mathrm{Ma}$.

Cores 35 to 41 lack significant datums because of poor preservation and cannot be correlated accurately to magnetostratigraphy. Good biostratigraphic resolution within the lower part of the section suggests a correlation of Core 594-42 through Core 594A-18 to paleomagnetic Chronozones 13 through upper 16. The base of Hole 594 is barren of diatoms but is younger than the first occurrence of the calcareous nannofossil Sphenolithus heteromorphus ( 17.5 Ma; Martini, this volume).

\section{TAXONOMIC REFERENCES}

Following is an alphabetical listing of diatom and silicoflagellate taxa cited in the range charts. It is not a complete list of all species in the assemblages. Since the emphasis in this study was on documenting the ranges of the predominant constituents of the assemblage, species represented by solitary occurrences were, in most cases, not included in the range charts. Because of time restrictions, emphasis was placed on species which characterize the assemblage or have potential use in biostratigraphy.

For each species, the first citation is the original description of the species. Subsequent citations are to more readily available references with descriptions, illustrations, and modern stratigraphic treatment. For species with more than one citation, only the more modern second citation is included in the reference list. The taxonomy follows that of Barron (1980a, b; 1983, in press) and Ciesielski (1983). References to the original species descriptions of the following taxa may be found in the publications already mentioned and in readily accessible papers dealing with Neogene subantarctic diatoms (McCollum, 1975; Schrader, 1976; Fenner et al., 1976; Gombos, 1976; Weaver and Gombos, 1981; and Ciesielski, 1983).

\section{Diatoms}

Actinocyclus ingens Rattray, 1890, p. 149, pl. 11, fig. 7; Schrader, 1973, pl. 18, figs. 2-4, 7; Kanaya, 1971, pl. 40.6, figs. 1-8. Re- 


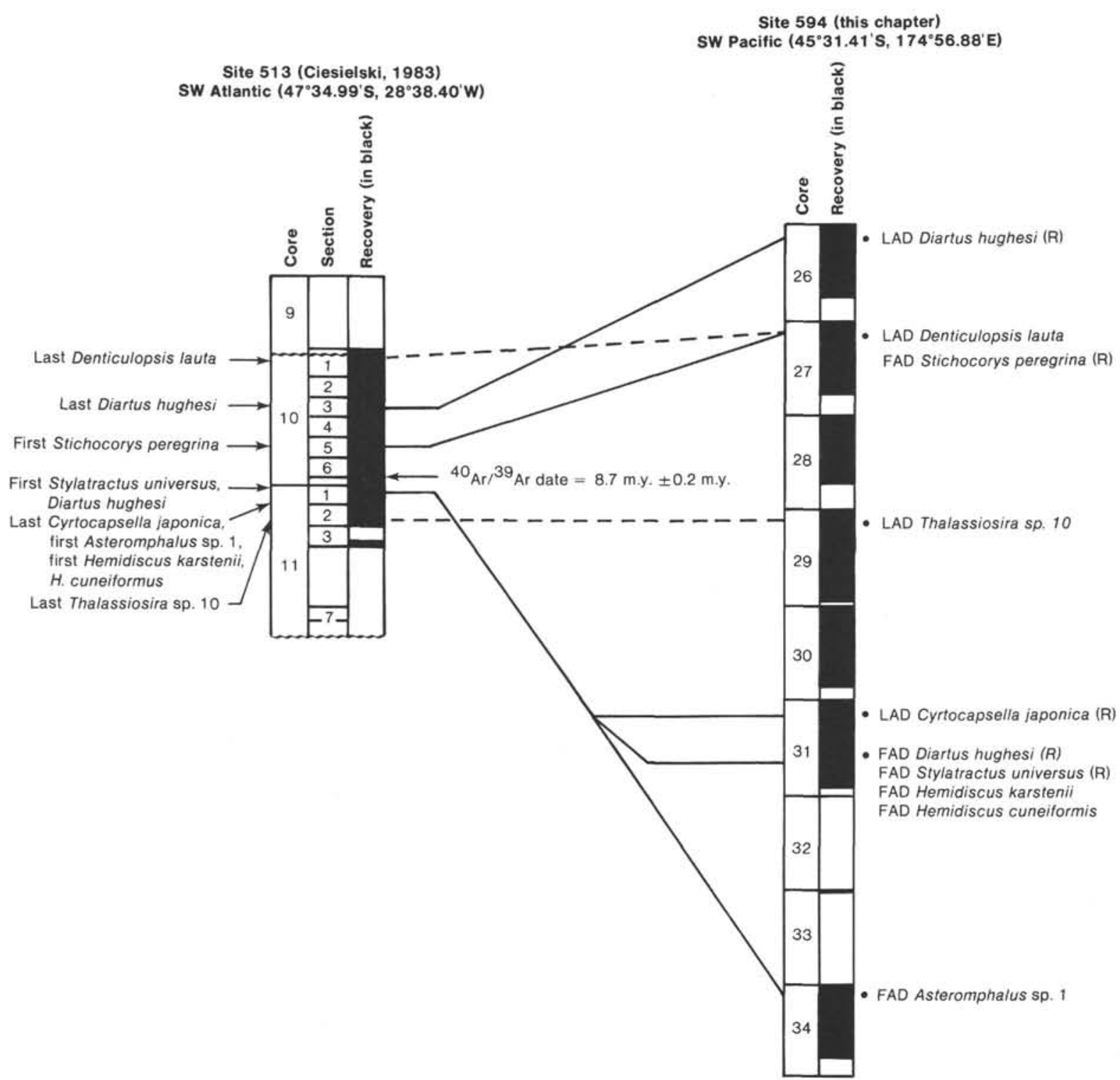

Figure 6. Radiolarian and diatom datums bracketing a radiometrically dated volcanic ash (Dallmeyer in Ciesielski, 1983) in the upper Miocene to DSDP Site 513 and a correlation of these datums to DSDP Site 594. This comparison suggests a very high sediment accumulation rate in Cores $34-26$ of Site 594. Based on this comparison, the $8.7 \pm 0.2 \mathrm{Ma}$ level in Site 594 falls between upper Core 29 and upper Core 27 . Dashed lines represent slightly diachronous datums.

marks: Miocene representatives of this species are tabulated separately as "flat forms" or "undulated forms" according to the criteria of Baldauf and Barron (1980). (Plate 1, Fig. 10, "flat form".) Actinocyclus ingens var. nodus Baldauf in Baldauf and Barron, 1980, p. 104, pl. 1, figs. 5-9. (Plate 1, Figs. 8-9.)

Actinocyclus ellipticus Grunow in Van Heurck, 1883, pl. 124, fig. 10; Schrader, 1973, pl. 8, figs. 7-9, 12-14, 16-17. (Plate 5, Fig. 8).

Actinocyclus ellipticus var. spiralis (Grunow) Barron, in press, a, pl. 7, figs. 9-10, pl. 9, fig. 5. (Plate 5, Figs. 6-7.)

Actinoptychus undulatus (Bailey) Ralfs in Pritchard, 1861; Hustedt, 1930, pp. 475-478, fig. 264; Schrader, 1973, pl. 22, figs. 4, 12, 15. Asteromphalus parvulus Karsten, 1905, p. 90, pl. 8, fig. 14; Hustedt, 1958 , p. 128, pl. 8, fig. 91; Schrader, 1976, pl. 8, figs. 3, 6 . Asteromphalus sp. 1 Ciesielski, 1983, p. 655, pl. 6, figs. 1-2, 6, 9. Asteromphalus sp. 2 Schrader, 1976, pl. 8, fig. 1.

Asteromphalus sp. 3 Ciesielski, 1983, pl. 6, fig. 5 .

Brunia mirabilis (Brun in Brun and Tempère) Tempère, 1890, plate 7, figs. 1-2. Barron, 1975, p. 127, pl. 4, fig. 16. Synonym: As Bruniopsis mirabilis (Brun) Karsten, referenced in Schrader, 1973, p. 702, pl. 13, fig. 16, and Gombos, 1977, p. 592, pl. 6, fig. 4 .
Cestodiscus peplum Brun, 1891, p. 6, pl. 19, fig. 5; Lohman, 1974, pl. 3, fig. 2; Barron, 1983, pl. 1, figs. 1, 2. (Plate 5, Fig. 10.)

Charcotia actinochilus (Ehrenberg) Hustedt, 1958, pp. 122-126, figs. 57-80; Fenner et al., 1976, p. 771, pl. 5, fig. 5.

Coscinodiscus deformans Schrader, 1976, p. 630, pl. 11, figs. 1-2.

Coscinodiscus elliptopora Donahue, 1970, p. 201, pl. 4, figs. e, i-m; McCollum, 1975, pl. 16, fig. 10; Gombos, 1976, pl. 3, figs. 1-3, 6, pl. 9, fig. 3. (Plate 1, Fig. 6.)

Coscinodiscus endoi Kanaya, 1959, pp. 76-77, pl. 3, figs. 8-11; Schrader, 1976 , p. 630 , pl. 11 , figs. $4,8-10,12$.

Coscinodiscus kolbei Jousé, 1962, pl. 2, fig. 4; McCollum, 1975, pl. 4, figs. 7-9; Gombos, 1976, pl. 6, fig. 3. (Plate 4, Figs. 1-4.)

Coscinodiscus lentiginosus Janish in Schmidt et al., 1886, pl. 58, fig. 11; Gombos, 1976, pl. 3, figs. 4, 5 .

Coscinodiscus lentiginosus var. obovatus (Castracane) Ciesielski, 1983, p. 653 , pl. 4 , figs. $6-8$.

Coscinodiscus lewisianus Greville s s.; Kolbe, 1954, pl. 2, fig. 21; Kanaya, 1971 , pl. 40.5 , figs. 4-6; Barron, 1983 , pl. 1, fig. 5 . Remarks: Included are specimens with length to width ratios of $5: 3$ or greater. (Plate 5, Figs. 1-4, 11.) 


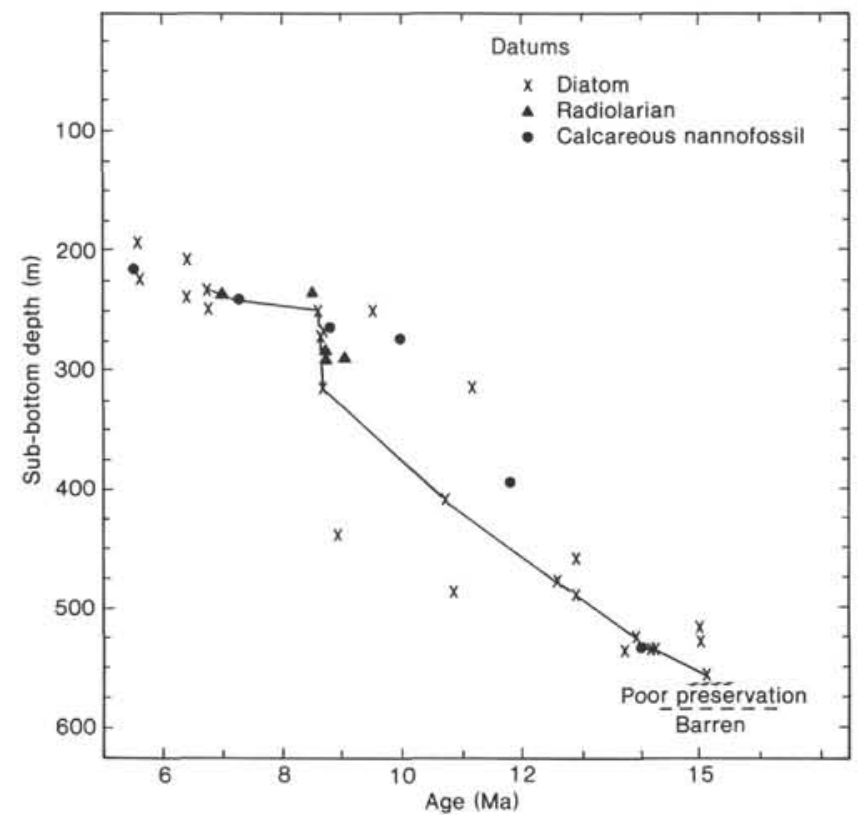

Figure 7. Age versus depth plot of the Miocene to Site 594 based on selected diatom, radiolarian, and calcareous nannofossil datums. Datum ages taken from Table 3.

Coscinodiscus lewisianus var. robustus Barron, 1983, p. 504, pl. 1, figs. 6-7. Remarks: Included are specimens with length to width ratios ranging from $4: 3$ to $8: 7$. (Plate 5, Fig. 5.)

Coscinodiscus aff. lineatus Ehrenberg, 1838; Schrader, 1976, p. 631, pl. 13, figs. $1,2$.

Coscinodiscus marginatus Ehrenberg, 1841, p. 142; Ehrenberg, 1854, pl. 18, fig. 44; Hustedt, 1930, p. 416, fig. 223.

Coscinodiscus praenitidus Fenner in Schrader and Fenner, 1976, p. 972, pl. 15 , fig. 7 , pl. 17 , fig. 8 .

Coscinodiscus ruboides Schrader, 1976, p. 631, pl. 6, figs. 4, 8.

Coscinodiscus vulnificus Gombos, 1977, p. 593, pl. 4, figs. 1-3, pl. 42, figs. 1-2.

Coscinodiscus yabei Kanaya, 1959, p. 86, pl. 5, figs. 6-9; Schrader, 1973 , p. 704 , pl. 6, figs. 1-6. (Plate 4, Figs. 7-10.)

Coscinodiscus aff. C. marginatus Ehrenberg, of Schrader, 1976, p. 631, pl. 10, fig. 3.

Cosmiodiscus insignis Jousé, 1961, p. 67, pl. 2, fig. 8; Koizumi, 1973, pl. 4, figs. 7-11; Gombos, 1976, pl. 4, figs. 4-5. Remarks: Whole valves of this species are rarely found intact in upper Gauss sediments of Southern Hemisphere mid-to high-latitude sediments. Plate 1, Figures 3-5 illustrate the most commonly recognized stages in the progressive dissolution of this species. (Plate 1, Figs. 1-5.)

Cosmiodiscus insignis f. triangula Jousé, 1977, pl. 79, fig. 2; Ciesielski, 1983, p. 656, pl. 5, figs. 1-10. (Plate 4, Figs. 5-6.)

Cosmiodiscus intersectus (Brun) Jousé, 1961, p. 68, pl. 2, figs. 9-10; Koizumi, 1973, p. 832, pl. 4, figs. 12-13.

Denticulopsis dimorpha (Schrader) Simonsen, 1979, p. 64. Synonym: Denticula dimorpha Schrader, 1973, p. 704, pl. 1, figs. 37-46; Barron, 1980a, pl. 1, fig. 21. (Plate 2, Figs. 5-8.)

Denticulopsis hustedtii (Simonsen and Kanaya) Simonsen, 1979, p. 64; Baldauf and Barron, 1982, pl. 7, figs. 7, 8. Synonym: Denticula hustedtii Simonsen and Kanaya, 1961, p. 501, pl. 1, figs. 19-25, pl. 2, figs. 36-47; Schrader, 1973, p. 704, pl. 2, figs. 28-34, 36-47. (Plate 2, Figs. 1-4.)

Denticulopsis hyalina (Schrader) Simonsen, 1979, p. 64; Baldauf and Barron, 1982, pl. 7, figs. 2, 4; Synonym: Denticula hyalina Schrader, 1973, p. 704, pl. 1, figs. 12-22. Remarks. In Site 594 this species is present in only two samples within the lower Coscinodiscus lewisianus Zone (NSD 4). In the North Pacific this species has a much longer range, having its last appearance in the upper Miocene $D$. hustedtii Zone, Subzone b. (Plate 2, Figs. 9-14.)

Denticulopsis lauta (Bailey) Simonsen, 1979, p. 64. Synonym: Denticula lauta Bailey, 1854, p. 9, figs. 1-2; Schrader, 1973, pl. 2, figs. 14-24, 35. Remarks: The lowermost range of this species may have been lost to dissolution.

Denticulopsis nicobarica (Grunow) Simonsen, 1979, p. 65; Baldauf and Barron, 1982, pl. 7, fig. 6; Synonym: Denticula nicobarica Grunow, 1868 , p. 97 , pl. 1a, fig. 5 . Remarks: The lowermost range of this species may have been lost to dissolution. (Plate 2, Figs. 20-22.)

Denticulopsis praedimorpha (Akiba, 1979) Barron, 1981, p. 529, pl. 4, figs. 8-10; Synonym: Denticula praedimorpha (Akiba, 1979) Barron, 1980a, pl. 1, figs. 18-20.

Denticulopsis punctata (Schrader) Simonsen, 1979, p. 65; Baldauf and Barron, 1982, pl. 7, fig. 7. Synonym: Denticula punctata 1973, p. 705 , pl. 1, figs. 25-30, pl. 3, figs. 16, 17. (Plate 2, Figs. 23-25.)

Denticulopsis punctata f. hustedtii (Schrader) Simonsen, 1979; Barron, 1981, pl. 4, fig. 1; Synonym: Denticula punctata f. hustedtii Schrader, 1973, p. 705, pl. 1, figs. 23, 24. (Plate 2, Figs. 15-19.)

Ethmodiscus rex (Wallich) Hendy in Wiseman and Hendy, 1953, p. 51 , pl. 1, fig. 1; Synonym: Coscinodiscus rex Wallich in Rattray 1980 , p. 568 , fig. 120 .

Eucampia antarctica (Castracane) Mangin; Fenner et al., 1976, p. 774, pl. 5, figs. 7-9.

Goniothectum odontella Ehrenberg, 1844, p. 82; Gombos and Ciesielski, 1983, pl. 22, fig. 9. Reworked.

Hemiaulus incisus Hajós, 1976, p. 829, pl. 23, figs. 4-9. Reworked.

Hemiaulus polycystinorum Ehrenberg, 1854, pl. 36, figs. 43a, b; renner, 1978 , p. 521, pl. 21 , figs. 13,14 ; pl. 22, figs. 4, 5, 7-10, pl. 23, figs. 1-4. Reworked.

Hemiaulus polymorphus Grunow, 1884, p. 66; Fenner, 1978, p. 522, pl. 21 , fig. 11 , pl. 23 , figs. 10,11 , pl. 22 , fig. 13 . Reworked.

Hemidiscus cuneiformis Wallich, 1860, p. 42, pl. 2, figs. 3, 4; Barron 1980 b, pl. 1, figs. 9, 10 .

Hemidiscus karstenii Jousé in Jousé et al., 1962, p. 78, pl. 2, figs. 7-9; Abbott, 1974, pl. 1, figs. D-F; Gombos, 1976, pl. 4, fig. 8.

Hemidiscus karstenii f. 1 Ciesielski, 1983, p. 656, pl. 4, figs. 2-5.

Hyalodiscus spp. Remarks: No attempt to differentiate species of the genus was made in the present study.

Lithodesmium cf. minusculum Grunow in Van Heurck, 1883; Schrader, 1973 , p. 706 , pl. 12, figs. 15, 17; Barron, 1976, pl. 1, figs. 15 , 16?; Ciesielski, 1983, p. 656. Remarks: Consistently present in the upper Miocene subantarctic DSDP Sites 594 and 513.

Lithodesmium aff. reynoldsii Barron, 1976, p. 53, pl. 1, figs. 17, 18?; Barron, 1981, pl. 5, fig. 7. Remarks: Specimens in Hole 594 are poorly preserved but appear to conform with the diagnosis by having punctae arranged in radial, linear rows, a small hyaline central area, one or two central nodules, straight or relatively straight valve margins, and a hyaline ring separating angles from the central body.

Lizitziana ornata Jousé, 1978, pp. 47-48, pl. 10, figs. 1-4; Gombos and Ciesielski, 1983, pl. 18, figs. 1-4. Synonym: Triceratium cruciforme Schmidt, 1887, pl. 77, fig. 41. Reworked.

Mediara splendida Scheschukova-Poretzkaja, 1962, p. 210, pl. 2, fig. 5; Baldauf and Barron, 1982, pl. 7, fig. 15.

Melosira architecturalis Brun, 1892, in Schmidt et al. (1874-__), pl. 177, figs. 45-50; Schrader and Fenner, 1976, p. 989, pl. 14, fig. 13 , pl. 29 , figs. $7-8$, pl. 35 , figs. 1-4. Reworked.

Nitzschia angulata (O'Meara) Hasle, 1972; Hasle, 1965, pp. 24-26, pl. 1, fig. 6, pl. 4, fig. 19, pl. 9, figs. 1-6; Fenner et al., 1976, p. 775 , pl. 1, figs. 17-39. (Plate 3, Fig. 13.)

Nitzschia denticuloides Schrader, 1976, p. 633, pl. 3, figs. 7-8, 10, 12, 18-24; pl. 15, fig. 22. Remarks: Most specimens of this species are poorly preserved, particularly in the lower portion of its range. (Plate 3, Fig. 18.)

Nitzschia aff. donahuensis Schrader, 1976, p. 633, pl. 2, fig. 30. Remarks: The specimen illustrated in Plate 3, Fig. 14 matches the description of Schrader (1976); however, the loss of one apex prevents a sure diagnosis because of the heteropolar nature of the species.

Nitzschia fossilis (Frenguelli) Kanaya in Kanaya and Koizumi, 1970; Schrader, 1974, p. 914, pl. 4, figs. 9-11, 24, 25; Barron, 1980a, pl. 2 , figs. 3,4 .

Nitzschia interfrigidaria (McCollum) Ciesielski, 1983, p. 655, pl. 1, figs. 11-18. (Plate 3, Figs. 6-7.)

Nitzschia januaria Schrader, 1976, p. 634, pl. 2, figs. 25-29. (Plate 3, Fig. 5.)

Nitzschia kerguelensis (O'Meara) Hasle, 1972; Hasle, 1965, pp. 14-18, pl. 4, figs. 11-18, pl. 7, fig. 9 (as Fragilariopsis kerguelensis O’Meara); Fenner et al., 1976, p. 776, pl. 2, figs. 19-30. 
Nitzschia marina Grunow in Cleve and Grunow, 1880, p. 70; Grunow in Van Heurck, 1881, pl. 57, figs. 26-27; Schrader, 1973, pl. 4, figs. 17-19; Schrader, 1974, pl. 5, figs. 1-2, 5, 14 ?.

Nitzschia miocenica Burckle, 1972, pp. 240-241, pl. 2, figs. 10-15; Barron, 1980a, p. 672 , pl. 2, fig. 8, pl. 3, figs. 3, 4.

Nitzschia porteri Frenguelli, 1949, p. 116, pl. 1, figs. 33-34; Schrader, 1973 , p. 707 , pl. 5 , figs. $35,36,39-41,43,44$.

Nitzschia praefossilis Schrader, 1973, p. 708, pl. 5, figs. 19, 21, 22.

Nitzschia praereinholdii Schrader, 1973, p. 708, pl. 5, figs. 20, 23, 26; Barron, 1981, pl. 4, fig. 16. (Plate 3, Fig. 15.)

Nitzschia reinholdii Kanaya and Koizumi, 1970; Schrader, 1973, p. 708, pl. 4, fig. 12-16, pl. 5, figs. 1-9; Barron, 1981, pl. 4, fig. 15. (Plate 3, Figs. 1-4.)

Nitzschia weaveri Ciesielski, 1983, p. 655, pl. 1, figs. 1-10. (Plate 3, Figs. 8-12.)

Nitzschia sp. 17 Schrader, 1976, p. 634, pl. 3, figs. 13-15, pl. 2, fig. 10.

Pterotheca aculeifera (Grunow) Van Heurck, 1896, p. 430, fig. 151; Fenner, 1978, p. 526, pl. 17, figs. 8-21; Synonym: Pyxilla aculeifera Grunow in Van Heurck, 1882, pl. 83, figs. 13, 14. Reworked.

Pyxilla fragments. Only reworked fragments of this genus were found in Neogene sediments.

Raphiodiscus marylandicus Christian, 1887; Schrader, 1973, p. 708, pl. 22, fig. 7; Andrews, 1974 , p. 232, pls. 1-5, figs. 1-29.

Raphoneis amphiceros Ehrenberg, 1844; Hustedt, 1959, p. 174, figs. 680-681; Schrader, 1973, pp. 708-709, pl. 25, figs. 2-3. Remarks: The present study follows Schrader (1973) by including only specimens with finely punctate apices, with a single mucous pore situated at each apex and excentric to the axial area. (Plate 6, Figs. 1-3.)

Rhaphoneis parilis Hanna, 1932, pp. 214-215, pl. 16, figs. 2-4; Lohman, 1948, p. 182, pl. 11, fig. 10. (plate 6, Fig. 6.)

Rhaphoneis sp. 1. Remarks: A great deal of morphologic variability was found in Rhaphoneis specimens in the interval encompassed by the ranges of $R$. amphiceros and $R$. parilis. These specimens have one mucous pore located excentrically at each apex but do not have finely punctate apices. Valve surfaces on the opposite sides of the pseudoraphe are often asymmetric in outline. (Plate 3, Figs. 19-21.)

Rhizosolenia barboi (Brun) Tempère and Peragallo, 1908, p. 26, No. 47; Schrader, 1973, p. 709, pl. 24, figs. 4, 7; Synonym: Pyxilla barboi Brun, 1894, p. 87, pl. 5, figs. 16, 17, and 23. (Plate 3, Fig. 22.)

Rhizosolenia hebatata Bailey, 1856, p. 5, pl. 1, figs. 18, 19.

Rhizosolenia hebatata forma hiemalis Gran, 1904, p. 527, pl. 27, fig. 9; Schrader, 1973, pl. 9, figs. 11, 13-17, 19-21, 24, 25.

Rhizosolenia praebarboi Schrader, 1973, p. 709, pl. 24, figs. 1-3; Barron, 1980a, pl. 2, fig. 18.

Rhizosolenia styliformis Brightwell, 1858, p. 95, pl. 5, figs. 5a, b and d; Hustedt, 1930, pp. 584-588, figs. 333-335; Schrader, 1973, pl. 10, figs. $1,18,19,20,21$; pl. 9, fig. 9 ? .

Rocella gelida (Mann) Bukry, 1978, p. 788, pl. 5, figs. 1-13; Gombos and Ciesielski, 1983, pl. 6, figs. 1-6, pl. 26, fig. 1. Reworked.

Rocella gelida var. schraderi (Bukry) Barron, in press b, fig. 4.15. Synonym: Rocella schraderii Bukry, 1978, p. 788, pl. 6, figs. 1-10, pl. 7, fig. 1; Gombos and Ciesielski, 1983, pl. 22, fig. 6. Reworked. (Plate 2, Fig. 26.)

Rocella vigilans (Schmidt) Fenner, 1982; Gombos and Ciesielski, 1983, p. 604 , pl. 6 , figs. $7-10$; pl. 26, fig. 2. Synonym: Coscinodiscus vigilans Schmidt, Jousé, 1974, pl. 3, fig. 16; Kolbe, 1954, pl. 1, figs. 13, 14. Reworked.

Stephanopyxis hyalomarginata Hajós, 1976, p. 824, pl. 19, figs. 11-12; Gombos and Ciesielski, 1983, pl. 10, figs. 1-6. Reworked.

Stephanopyxis turris (Greville et Arnott) Ralfs in Pritchard, 1861, p. 826 , pl. 5, fig. 74; Fenner, 1978, p. 532, pl. 12, figs. 8, 9. Synonym: Cresswellia turris Greville and Arnott, 1857, p. 538. (Plate 1, Fig. 7.)

Synedra jouseana Sheshukova-Poretzkaya, 1962, p. 208, fig. 4; Schrader, 1973, pl. 23, figs. 21-23, 25, 28.

Thalassionema hirosakiensis (Kanaya) Schrader, 1973, p. 711, pl. 23, figs. 31-33.

Thalassionema nitzschioides (Grunow) Van Heurck, 1896, p. 319, fig. 75; Schrader, 1973, pl. 23, figs. 2, 6, 8, 9, 10, 12-13, 26, 29, 34. (Plate 3, Fig. 17.)

Thalassiosira torokina Brady, 1977, pp. 122-123, figs. 1-5; Ciesielski, 1983, pl. 7, figs. 3-6.

Thalassiosira sp. 10 Schrader, 1976, p. 637, pl. 15, figs. 6-8.
Thalassiothrix spp. All species of Thalassiothrix are so tabulated in Table 2 , except $T$. miocenica, which is tabulated separately.

Thalassiothrix miocenica Schrader, 1973, p. 713, pl. 23, figs. 2-5.

Triceratium groningensis Reinhold, 1937, p. 126, pl. 20, fig. 9; Fenner, 1979 , p. 534, pl. 30, figs. 21-22. Reworked.

Trinacria excavata Heiberg, 1863; Hustedt, 1930, pp. 887-888, fig. 532; McCollum, 1975, pl. 13, fig. 6 .

Trinacria simulacrum Grove and Sturt, 1887, p. 144, pl. 13, fig. 46; Fenner, 1978, p. 536, pl. 19, fig. 2; pl. 31, fig. 2.

Xanthiopyxis acrolophra Forti, 1913; Kanaya, 1959, p. 159, pl. 11, fig. 8 .

\section{Silicoflagellates}

Corbisema apiculata (Lemmermann) Hanna, 1931; Shaw and Ciesielski, 1983, p. 706, pl. 1, figs. 1-3. Reworked.

Corbisema archangelskiana (Schulz) Frenguelli, 1940, fig. 12a; Shaw and Ciesielski, 1983, pl. 19, figs. 1-4, 6; pl. 20, fig. 1. Reworked.

Corbisema disymmetrica communis Bukry, 1976, p. 891, pl. 1, figs. 1-4; Synonym: Corbisema navicula navicula (Ehrenberg) Busen and Wise, 1977, p. 712, pl. 2, figs. 7-9. Reworked.

Corbisema geometrica Hanna, 1928, no. 4, p. 261, pl. 41, figs. 1, 2 (fide Loeblich et al., 1968, p. 75). Reworked.

Corbisema triacantha (Ehrenberg) Hanna, 1931; Ling, 1973, pl. 1, figs. 7, 8; Bukry and Foster, 1973, p. 826, pl. 2, fig. 3; Bukry, 1973, pl. 1, fig. 2 .

Dictyocha frenguelli Deflandre, 1950, p. 194, figs. 188-193. Reworked.

Dictyocha spp. Remarks: Dictyocha species are not differentiated herein.

Distephanus boliviensis (Frenguelli) Bukry and Foster, 1973, p. 187, pl. 4, figs. 1-3; Shaw and Ciesielski, p. 713, pl. 10, figs. 5, 8 .

Distephanus crux crux (Ehrenberg) Haeckel, 1887, p. 1563 (fide Glezer, 1966, pp. 279-280); Shaw and Ciesielski, 1983, p. 713, pl. 10, figs. $6-7$; pl. 11, fig. 1 .

Distephanus polyactis (Ehrenberg) Deflandre, 1932, p. 501, fig. 40.

Mesocena apiculata (Schulz) Hanna, 1931; Shaw and Ciesielski, 1983, p. 714 , pl. 12 , figs. $1-7$. Reworked.

Mesocena circulus (Ehrenberg) Ehrenberg, 1844; Ling, 1972, p. 175, pl. 28, figs. 5, 6 .

Mesocena diodon Ehrenberg, 1844, pp. 71, 84; Shaw and Ciesielski, 1983, p. 714; Ciesielski, 1975, p. 661, pl. 12, figs. 1-3.

Mesocena oamaruensis Schulz, 1928; Shaw and Ciesielski, 1983, p. 714, pl. 12 , figs. $8-10$, pl. 13 , figs. $1-9$, pl. 14 , figs. 1-2. Reworked.

Mesocena occidentalis Hanna, 1931; Shaw and Ciesielski, 1983, p. 714, pl. 13, figs. 3-8. Reworked.

Naviculopsis biapiculata (Lemmermann) Frenguelli, 1940; Shaw and Ciesielski, 1983 , p. 715 , pl. 14 , figs. $11-13$, pl. 15 , figs. $1-3$. Reworked.

Naviculoposis constricta (Schulz) Frenguelli, 1940; Shaw and Ciesielski, 1983 , p. 715 , pl. 15 , figs. 4-8. Reworked.

Naviculopsis navicula var. naviculopsis (Deflandre) Tsumura, 1963; Ciesielski, 1975, pl. 13, figs. 2, 3 .

Naviculopsis trispinosa (Schulz) Glezer, 1966; Ciesielski, 1975, pl. 13, figs. 13, 14. Reworked.

\section{Incertae Sedis}

Macrora stella (Azpeitia) Hanna, 1932, p. 196, pl. 12, fig. 7; Schrader, 1973, pl. 12, figs. 21-24.

\section{ACKNOWLEDGMENTS}

Research supported by NSF grant DPP-81-13147 to M. T. Ledbetter and P. F. Ciesielski and NSF grant DPP-83-16679 to P. F. Ciesielski. Andrew M. Gombos, Jr., and John A. Barron are thanked for critical review of the manuscript.

\section{REFERENCES}

Baldauf, J. G., and Barron, J. A., 1980. Actinocyclus ingens var. nodus: A new, stratigraphically useful diatom of the circum-North Pacific. Micropaleontology, 26:103-110.

Barron, J. A., 1975. Late Miocene-early Pliocene marine diatoms from southern California. Palaeontographica B, 151:97-170.

1976. Revised Miocene and Pliocene diatom biostratigraphy of Upper Newport Nay, Newport Beach, California. Mar. Micropaleontol., 1:27-63. 
, 1980a. Lower Miocene to Quaternary diatom biostratigraphy of Leg 57, off northeastern Japan, Deep Sea Drilling Project In Scientific Party, Init. Repts. DSDP, 56, 57, Pt. 2: Washington (U.S. Govt. Printing Office), 641-685.

, 1980b. Upper Pliocene and Quaternary diatom biostratigraphy of Deep Sea Drilling Project Leg 54, tropical Eastern Pacific. In Rosendahl, B. R., Hekinian, R., et al., Init. Repts. DSDP, 54: Washington (U.S. Govt. Printing Office), 455-462.

1981. Late Cenozoic diatom biostratigraphy and paleoceanography of the middle-latitude eastern North pacific, Deep Sea Drilling Project Leg 63. In Yeats, R. S., Haq, B., et al., Init. Repts. DSDP, 63: Washington (U.S. Govt. Printing Office), 507-538.

1983. Latest Oligocene through early middle Miocene diatom biostratigraphy of the eastern tropical Pacific. Mar. Micropaleontol., 7:487-515.

in press, a. Late Eocene diatom biostratigraphy of the equatorial Pacific Ocean, DSDP Leg 85. In Mayer, L. Theyer, F., et al., Init. Repts. DSDP, 85: Washington (U.S. Govt. Printing Office). , in press, b. Neogene planktic diatom biostratigraphy. In Saunders, J. B., Bolli, H. M. (Eds.), Biostratigraphy by Marine Plankton: Cambridge (Cambridge Univ. Press).

Barron, J. A., and Keller, G., 1983. Paleotemperature oscillations in the middle and late Miocene of the northeastern Pacific. Micropaleontology, 29(2):150-181.

Barron, J. A., Keller, G., and Dunn, D. A., in press. A multiple microfossil biochronology for the Miocene. Geol. Soc. Am. Mem.

Berggren, W. A., 1981. Correlation of Atlantic, Mediterranean and Indo-Pacific Neogene stratigraphies: Geochronology and Chronostratigraphy. Proc. IGCP-114 Int. Workshop Pacific Neogene Biostratigraphy, Nov. 25-29, 1981, Osaka, Japan, pp. 29-60.

Berggren, W. A., Kent, D. V., and Flynn, J. J., in press. Paleogene geochronology and chronostratigraphy. In Snelling, N. J. (Ed.), Geochronology and the Geological Record. Geol. Soc. London, Spec. Paper.

Berggren, W. A., and Van Couvering, J. A., 1974. The Late Neogene: biostratigraphy, geochronology and paleoclimatology of the last 15 million years in marine and continental sequences. Palaeogeogr., Palaeoclimatol., Palaeoecol., 16:1-216.

Brady, H. T., 1977. Thalassiosira torokina n.sp. (diatom) and its significance in Late Cenozoic biostratigraphy. Antarctic J. U.S., 12: 122-123.

Bukry, D., 1976. Cenozoic silicoflagellate and coccolith stratigraphy, South Atlantic Ocean, Deep Sea Drilling Project Leg 36. In Hollister, C. D., Craddock, C., et al., Init. Repts. DSDP, 35: Washington (U.S. Govt. Printing Office), 845-872.

Burckle, L. H., 1972. Late Cenozoic planktonic diatom zones from the eastern equatorial Pacific: Nova Hedw., Beihft., 39:217-250. 1978. Early Miocene to Pliocene diatom datum levels for the equatorial Pacific. Proc. Second Working Group Meeting, Biostratigraphic Datum-Planes of the Pacific Neogene, IGCP Project 114. Republic of Indonesia Ministry of Mines and Energy, Directorate General of Mine, Geological Research and Development Center, Spec. Publ., 1:25-44.

Burckle, L. H., Keigwin, L. D., and Opdyke, N. D., 1982. Middle and late Miocene stable isotope stratigraphy: correlation to the paleomagnetic reversal record. Micropaleontology, 28:329-334.

Ciesielski, P. F., 1975. Biostratigraphy and paleoecology of Neogene and Oligocene silicoflagellates from cores recovered during Antarctic Leg 28, Deep Sea Drilling Project. In Hays, D. E., Frakes, L. A., et al., Init. Repts. DSDP, 28: Washington (U.S. Govt. Printing Office), 625-691.

1983. The Neogene and Quaternary diatom biostratigraphy of subantarctic sediments, Deep Sea Drilling Project Leg 71. In Ludwig, W. J., Krasheninnikov, V. A., et al., Init. Repts. DSDP, 71: Washington (U.S. Govt. Printing Office), 635-665.

Cita, M. B., 1975. The Miocene/Pliocene boundary: history and definition. In Saito, T., and Burckle, L. H. (Eds.) Late Neogene Epoch Boundaries: New York (Micropaleontology Press), pp. 1-30.

Deflandre, G., 1932. Sur la systématique des silicoflagellés. Soc. Bot. Fr. Bull., 79:494-506.

Donahue, J. G., 1970. Pleistocene Diatoms as Climatic Indicators in North Pacific Sediments. Geol. Soc. Am. Mem., 126.

Fenner, J., 1978. Cenozoic diatom biostratigraphy of the equatorial and southern Atlantic Ocean. In Supko, P. R., Perch-Nielsen, K., et al., Init. Repts. DSDP, Suppl. to Vols. 38, 39, 40, and 41: Washington (U.S. Govt. Printing Office), 491-623.

1982. Diatoms in the Eocene and Oligocene sediments off N.W. Africa, their stratigraphic and paleogeographic occurrences [Ph.D. dissert.]: Kiel (University of Kiel).

Fenner, J., Schrader, H.-J., and Wienigk, H., 1976. Diatom phytoplankton studies in the southern Pacific Ocean, composition and correlation to the Antarctic Convergence and its paleoecological significance. In Hollister, C. D., and Craddock, C., et al., Init. Repts. DSDP, 35: Washington (U.S. Govt. Printing Office), 757-813.

Gombos, A. M., Jr., 1976. Paleogene and Neogene diatoms from the Falkland Plateau and Malvinas Outer Basin: Leg 36 Deep Sea Drilling Project. In Barker, P. F., Dalziel, I. W. D., et al., Init. Repts. DSDP, 36: Washington (U.S. Govt. Printing Office), 575-687.

Gombos, A. M., Jr., and Ciesielski, P. F., 1983. Late Eocene to Early Miocene diatoms from the southwest Atlantic. In Ludwig, W. F., Krasheninnikov, V. A., et al., Init. Repts. DSDP, 71: Washington (U.S. Govt. Printing Office), 583-634.

Hajós, M., 1976. Upper Eocene and lower Oligocene diatomaceae, Archaeomonadaceae, and Silicoflagellatae in Southwestern Pacific sediments, DSDP Leg 29. In Hollister, C. D., Craddock, C., et al., Init. Repts. DSDP, 35: Washington (U.S. Govt. Printing Office), 817-883.

Hanna, G. D., 1928. Silicoflagellatae from the Cretaceous of California. J. Paleontol., 1(4):259-264.

1931. Diatoms and silicoflagellates of the Kreyenhagen Shale. Rept. State Mineral., pp. 187-201.

1932. The diatoms of Sharktooth Hill, Kern County, California: Calif. Acad. Sci. Proc., 20:161-263.

Hasle, G., 1965. Nitzschia and Fragilariopsis, species studied in the light and electron microscopes. III. The genus Fragilariopsis: Skr. Nor. Videnskaps-Akad I. Mat.-Naturvidensk Kl., 21:1-49.

Hustedt, F., 1930. Die Kieselalgen Deutschlands, Osterreichs, und der Schweiz mit Berücksichtigung der übrigen Länder Europas sowie der angrenzenden Meeresgebiete. In Rabenhorst, L. (Ed.), Kryptogamen-Flora von Deutschland, Osterreich und der Schweiz. Vol. 7, Pt. 1: Leipzig (Akademische Verlagsgesellschaft).

1958. Diatomeen aus der Antarktik und dem Sudatlantik. Deutsche Antarktische Exped. (Vol. 2).

Johnson, D. A., and Wick, B. J., 1982. Precision of correlation of radiolarian datum levels in the middle Miocene equatorial pacific. Micropalentology, 28:1-30.

Jousé, A. P., 1961. Miocene and Pliocene marine diatoms from the Far East. Akad. Nauk SSSR, Bot. Inst. In. V. L. Komarova, Otd. Sporov. Rast., Bot. Mat., 14:59-70. (In Russian.)

1962. Stratigraphische und Palaogeographische Untersuchungen im Nordwestteil des Pazifik, (vol. 5): Moscow (USSR Academy of Sciences).

1978. New fossil genus of diatoms (Lisitzinia [Bacillariophyta]). Marsk. Mikropaleontol. (Moscow), pp. 47-48.

Kahn, M. J., Miller, K. G., Kent, D. V., Aubry, M.-P., and Berggren, W. A., 1984. Oligocene-Miocene magnetobiostratigraphy of the Western North Atlantic: Age of the middle/late Miocene boundary. Trans. Am. Geophys. Union, 65:199. (Abstract.)

Kanaya, T., 1959. Miocene diatom assemblages from the Onnagawa Formation and their distribution in the correlative formations in northeast Japan: Sci. Rept. Tohoku Univ., Ser. 2 (Geol.), 30:1-130.

Koizumi, I., 1973. The Late Cenozoic diatoms of Sites 183-193, Leg 19, Deep Sea Drilling Project. In Creager, J. S., Scholl, D. W., et al., Init. Repts. DSDP, 19: Washington (U.S. Govt. Printing Office), 805-855.

1977. Diatom biostratigraphy in the North Pacific region. Proc. First Congr. Pacific Neogene Stratigraphy: Tokyo (Kaiyo Shuppan), pp. 235-253.

Kolbe, R. W., 1954. Diatoms from equatorial Pacific cores. In Petterson, H. (ed.), Rept. Swed. Deep-Sea Exped. 1947-1948, 6:1-49.

LaBrecque, J. L., Kent, D. V., and Cande, S. C., 1977. Revised magnetic polarity time scale for Late Cretaceous and Cenozoic time. Geology, 5:330-335.

Ling, H. Y., 1972. Upper Cretaceous and Cenozoic silicoflagellates and ebridians. Bull. Am. Paleontol., 62:125-229.

Lohman, K. E., 1974. Lower middle Miocene marine diatoms from Trinidad. Verh. Nat. Ges. Basel, pp. 1-47. 
McCollum, D. W., 1975. Diatom stratigraphy of the Southern Ocean. In Hayes, D. and Frakes, L. A., et al., Init. Repts. DSDP, 28: Washington (U.S. Govt. Printing Office), 515-571.

Martini, E., 1971. Standard Tertiary and Quaternary calcareous nannoplankton zonation. In Farinacci, A. (Ed.), Proc. II Planktonic Conf., Roma, 1970 (Vol. 2): Rome (Edizioni Tecnoscienza), 739-777.

Ryan, W. B. F., Cita, M. B., Rawson, M., Burckle, L. H., and Saito, T., 1974. A paleomagnetic assignment of Neogene stage boundaries and the development of isochronous datum planes between the Mediterranean, the Pacific, and Indian Oceans in order to investigate the response of the world ocean to the Mediterranean "salinity crisis." Riv. Ital. Paleontol., 80:631-688.

Schrader, H.-J., 1973. Cenozoic diatoms from the northeast Pacific, Leg 18. In Kulm, L. D., von Huene, R., et al., Init. Repts. DSDP, 18: Washington (U.S. Govt. Printing Office), 673-797.

1976. Cenozoic planktonic diatom biostratigraphy of the Southern Ocean. In Hollister, C. D., Craddock, C., et al., Init. Repts. DSDP, 35: Washington (U.S. Govt. Printing Office), 605-671.

Schrader, H.-J., and Fenner, J., 1976. Norwegian Sea Cenozoic diatom biostratigraphy and taxonomy. In Talwani, M., Udintsev, G., et al., Init. Repts. DSDP, 38: Washington (U.S. Govt. Printing Office), 921-1098.

Shaw, C. A., and Ciesielski, P. F., 1983. Silicoflagellate biostratigraphy of middle Eocene to Holocene subantarctic sediments recov- ered by Deep Sea Drilling Project Leg 71. In Ludwig, W. J., Krasheninnikov, V. A., et al., Init. Repts. DSDP, 71: Washington (U.S. Govt. Printing Office), 687-737.

Simonsen, R., 1979. The diatom system: Ideas on phylogeny. Bacillaria, 2:9-79.

Tauxe, L., Opdyke, N. D., Pasini, G., and Elmi, C., 1983. Age of the Plio-Pleistocene boundary in the Vrica section, southern Italy. $\mathrm{Na}$ ture, 304:125-129.

Theyer, F., and Hammond, S. R., 1974. Paleomagnetic polarity sequence and radiolarian zones, Brunhes to polarity epoch 20. Earth Planet. Sci. Lett., 22:307-319.

Theyer, F., Mato, C. Y., and Hammond, S. R., 1978. Paleomagnetic and geochronologic calibration of latest Oligocene to Pliocene radiolarian events, equatorial Pacific. Mar. Micropaleontol., 3: 377-395.

Weaver, F. M., and Gombos, A. M., 1981. Southern high latitude diatom biostratigraphy. In Warme, T. E., Douglas, R. C., and Winterer, E. L. (Eds.), The Deep Sea Drilling Project: A Decade of Progress. Soc. Econ. Paleont. Mineral., Spec. Publ., 32:445-470.

Wiseman, D., and Hendy, N., 1953. The significance and diatom content of a deep-sea floor sample from the neighbourhood of the greatest oceanic depth. Deep-Sea Res., 1:47-59.

Date of Initial Receipt: 24 September 1984 Date of Acceptance: 7 February 1985 

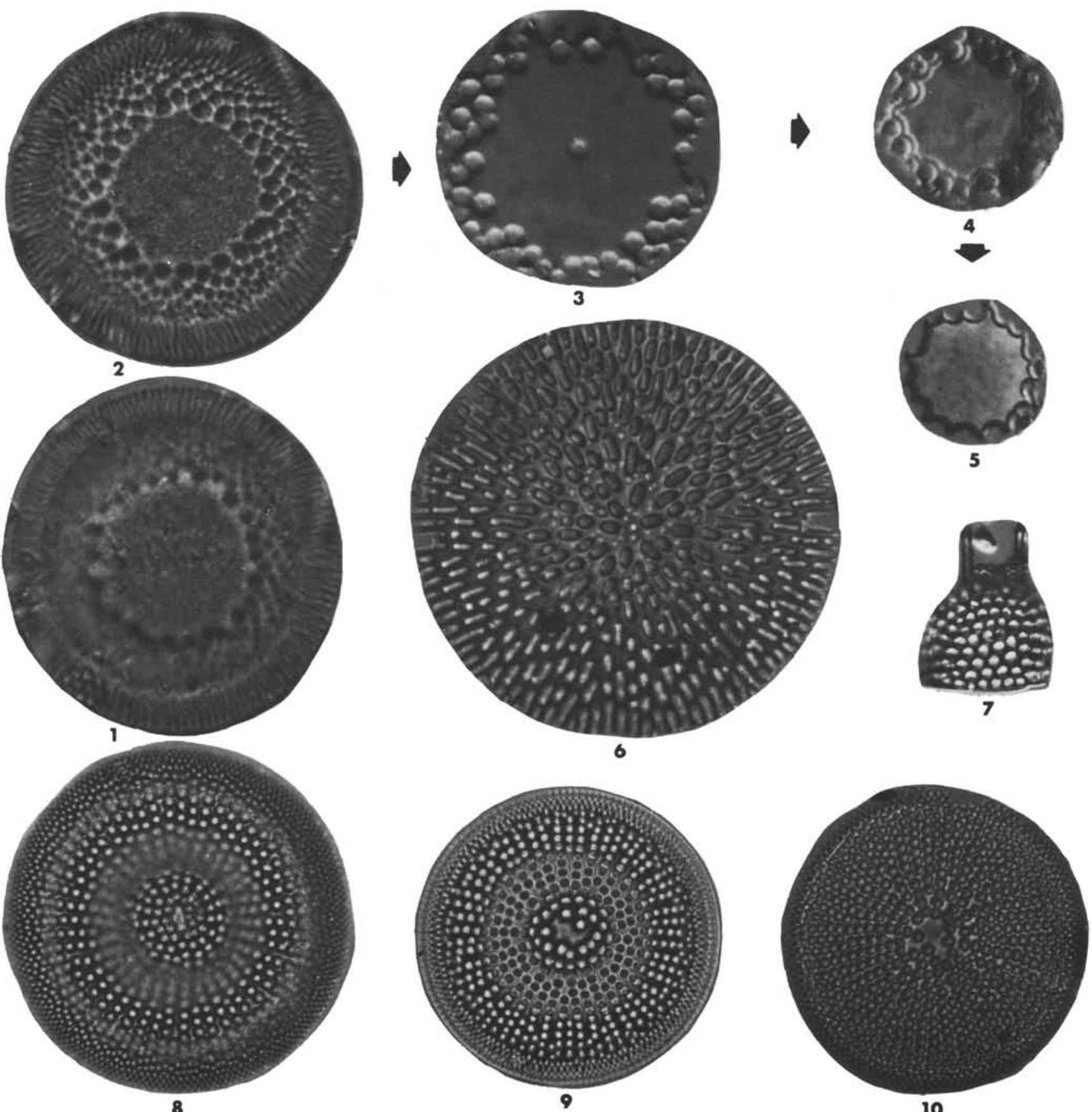

Plate 1. 1-5. Cosmiodiscus insignis Jousé, $\times 1500$, (1-2) Sample 594-16-5, 4-5 cm, (3-5) Sample 594-16-2, 4-5 cm. 6. Coscinodiscus elliptopora Donahue, $\times 1000$, Sample 594A-5-5, 4-5 cm. 7. Stephanopyxis turris Ralfs, $\times 750$, Sample 594-20-2, 4-5 cm. 8-9. Actinocyclus ingens var. nodus Baldauf, $\times 750$, Sample 594A-18-2, 4-5 cm. 10. Actinocyclus ingens Rattray (flat form), $\times 1000$, Sample 594-9-5, 4-5 cm. 


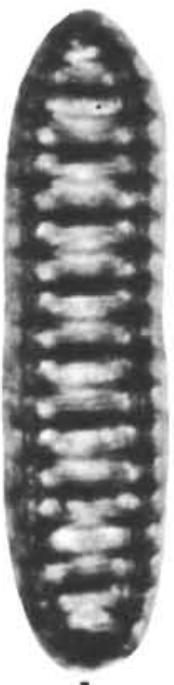

1
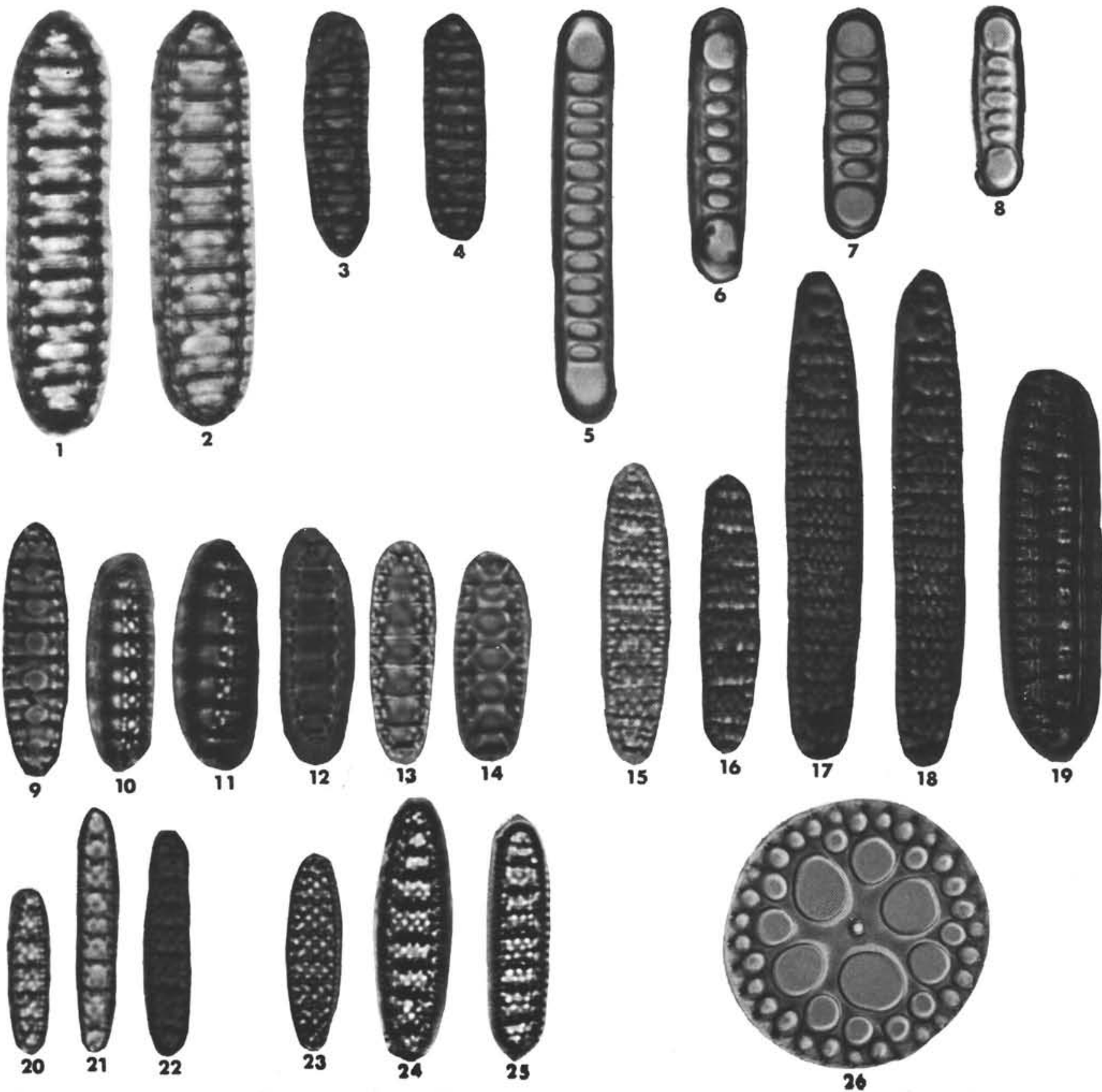

Plate 2. 1-4. Denticulopsis hustedtii (Simonsen and Kanaya) Simonsen, $\times 1500$, (1-2) Sample 594-49-2, 4-5 cm, (3-4) Sample 594-31-2, 4-5 cm. 5-8. Denticulopsis dimorpha (Schrader) Simonsen, $\times 1500$, (5, 7) Sample 594-44-1, 4-5 cm, (6) Sample 594-45-2, 4-5 cm, (8) Sample 594-47-1, 4-5 cm. 9-14. Denticulopsis hyalina (Schrader) Simonsen, $\times 1500,(9-10,12-14)$ Sample 594A-15-2, 4-5 cm, (11) Sample 594A-14-2, 4-5 $\mathrm{cm}$. 15-19. Denticulopsis punctata f. hustedtii (Schrader) Simonsen, $\times 1500$, (15-18) Sample 594-47-1, 4-5 cm, (19) Sample 594A-15-2, 4-5 cm. 20-22. Denticulopsis nicobarica (Grunow) Simonsen, $\times 1500$, Sample 594A-16-5, 4-5 cm. 23-25. Denticulopsis punctata (Schrader) Simonsen, $\times 1500$, Sample 594A-16-2, 4-5 cm. 26. Rocella gelida var. schraderi (Bukry) Barron, $\times 750$, Sample 594-44-1, 4-5 cm. 


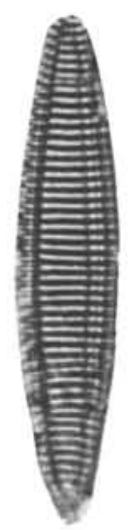

1

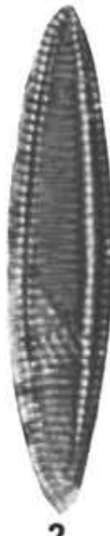

2

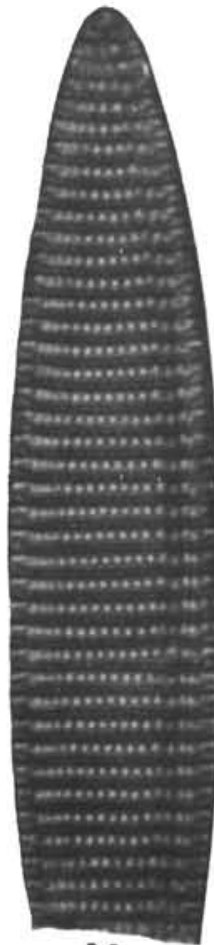

14
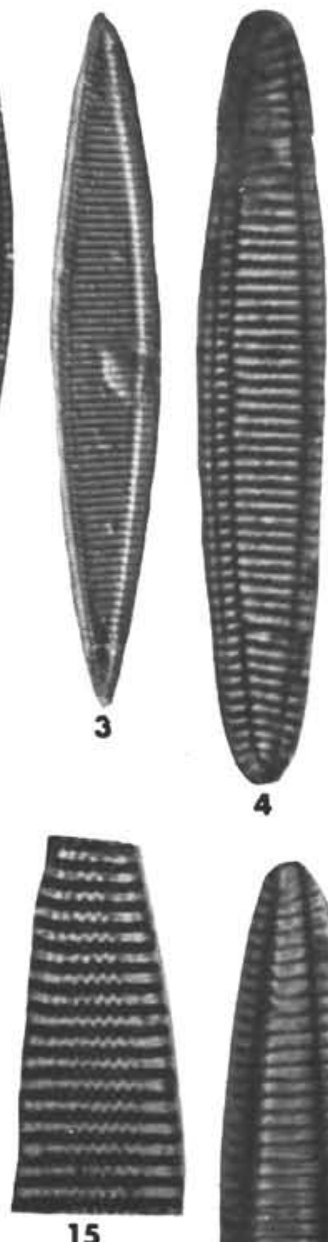

15
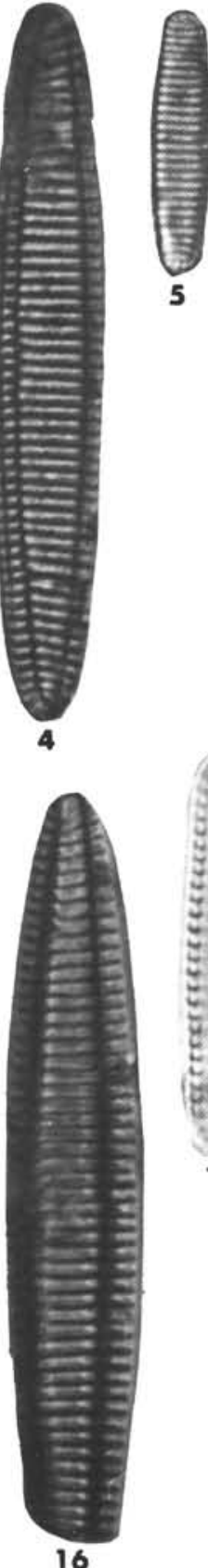
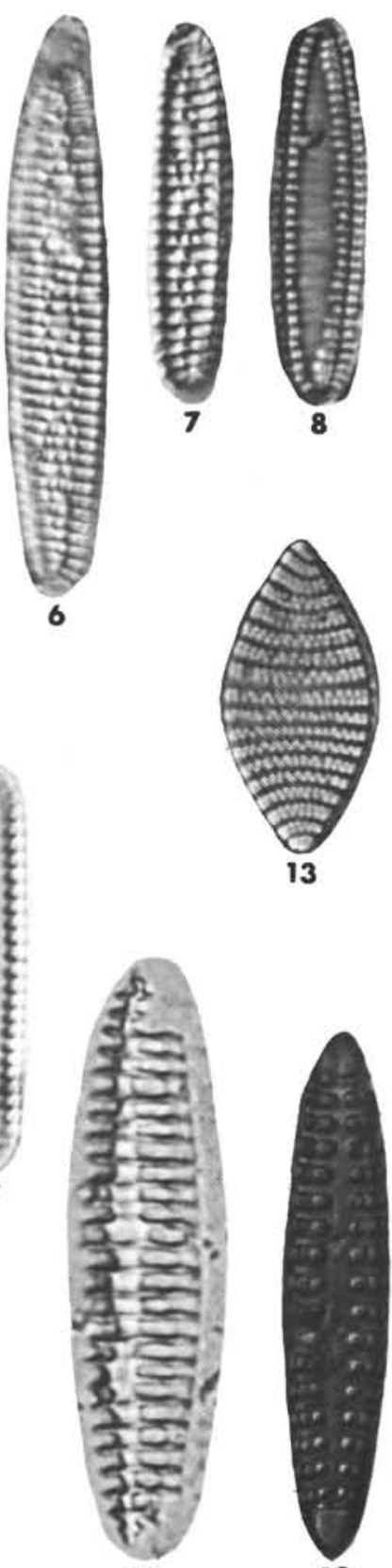

18

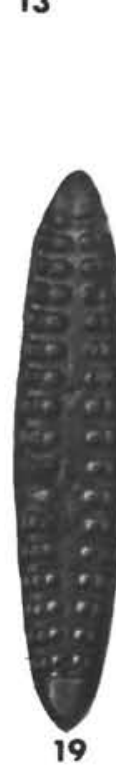

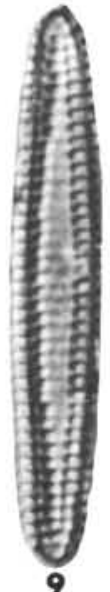
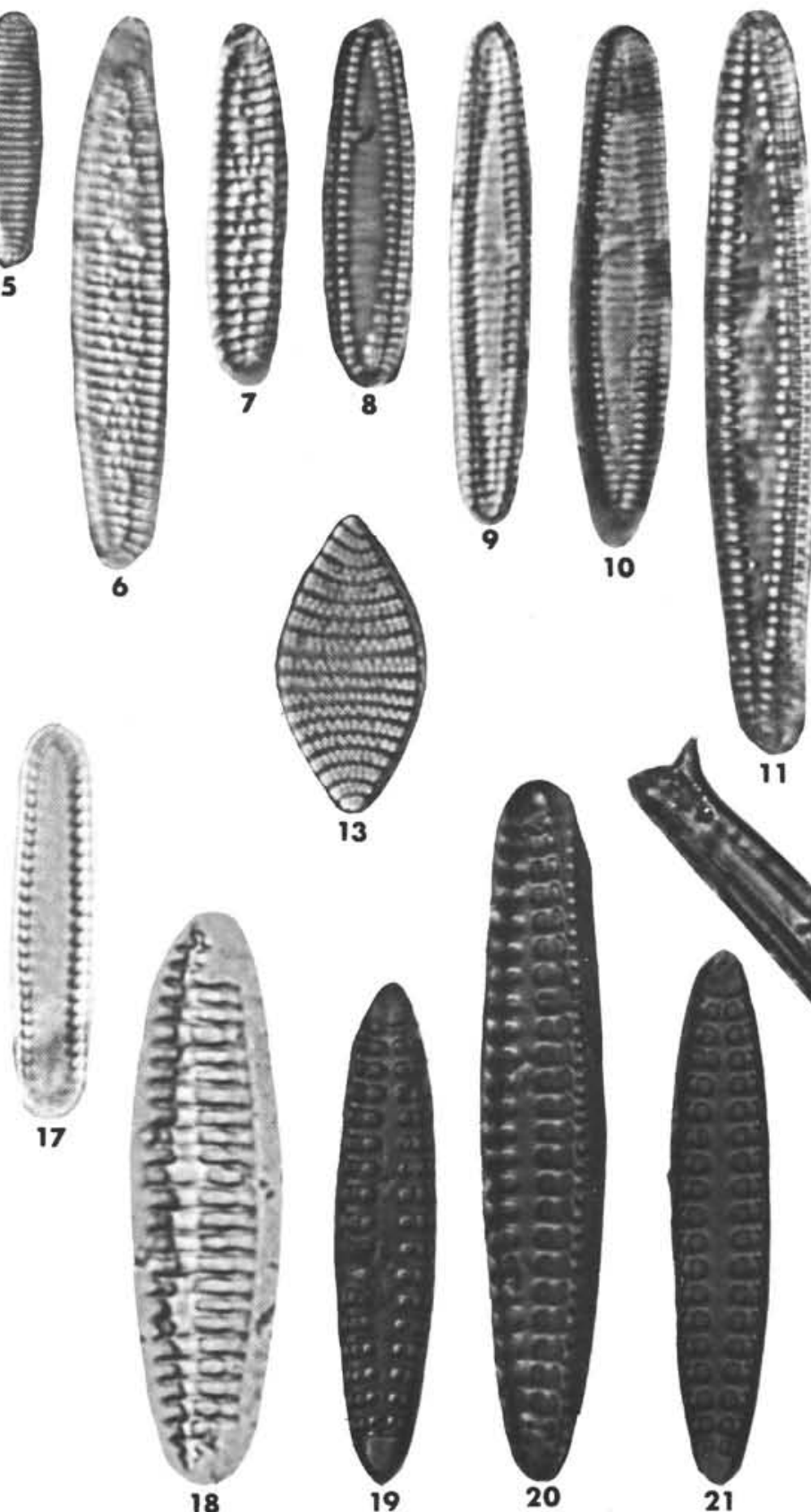

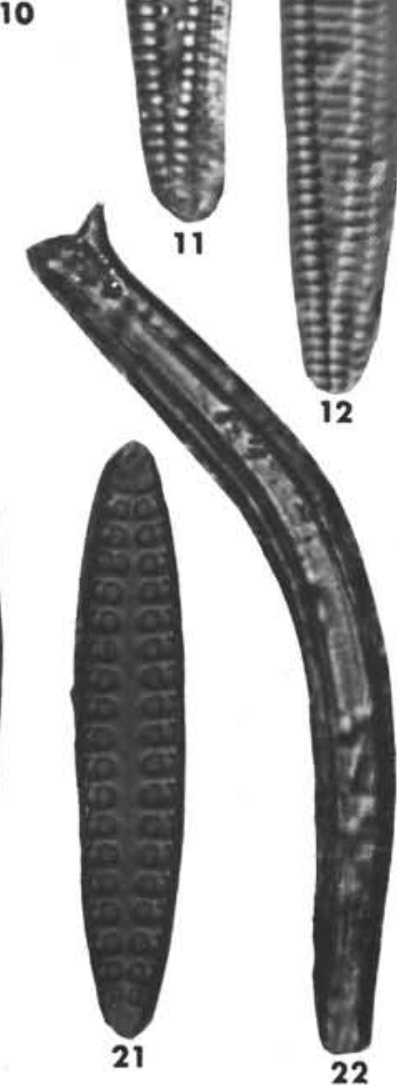

Plate 3. 1-4. Nitzschia reinholdii Kanaya and Koizumi, $\times 1000$, Sample 594-23-5, 4-5 cm. 5. Nitzschia januaria Schrader, $\times 1500$, Sample 594-23-5, 4-5 cm. 6-7. Nitzschia interfrigidaria (McCollum) Ciesielski, Sample 594A-10-5, 4-5 cm. 8-12. Nitzschia weaveri Ciesielski, $\times 1500$, Sample 594-16-5, 4-5 cm. 13. Nitzschia angulata (O'Meara) Hasle, $\times 1500$, Sample 594-15-2, 4-5 cm. 14. Nitzschia aff. donahuensis Schrader, $\times 1500$, Sample 594-38-2, 4-5 cm. 15. Nitzschia praereinholdii Schrader, $\times 1500$, Sample 594-28-2, 4-5 cm. 16. Nitzschia mioceni$c a$ (Burckle), $\times 1500$, Sample 594-27-2, 4-5 cm. 17. Thalassionema nitzschioides Grun, $\times 1500$, Sample $594 \mathrm{~A}-15-2,4-5 \mathrm{~cm}$. 18. Nitzschia denticuloides Schrader, $\times 1500$, Sample 594-47-1, 4-5 cm. 19-21. Rhaphoneis sp. 1, $\times 1000$, Sample 594-31-5, 4-5 cm. 22. Rhizosolenia barboi Brun, $\times 1000$, Sample 594-21-5, 4-5 cm. 

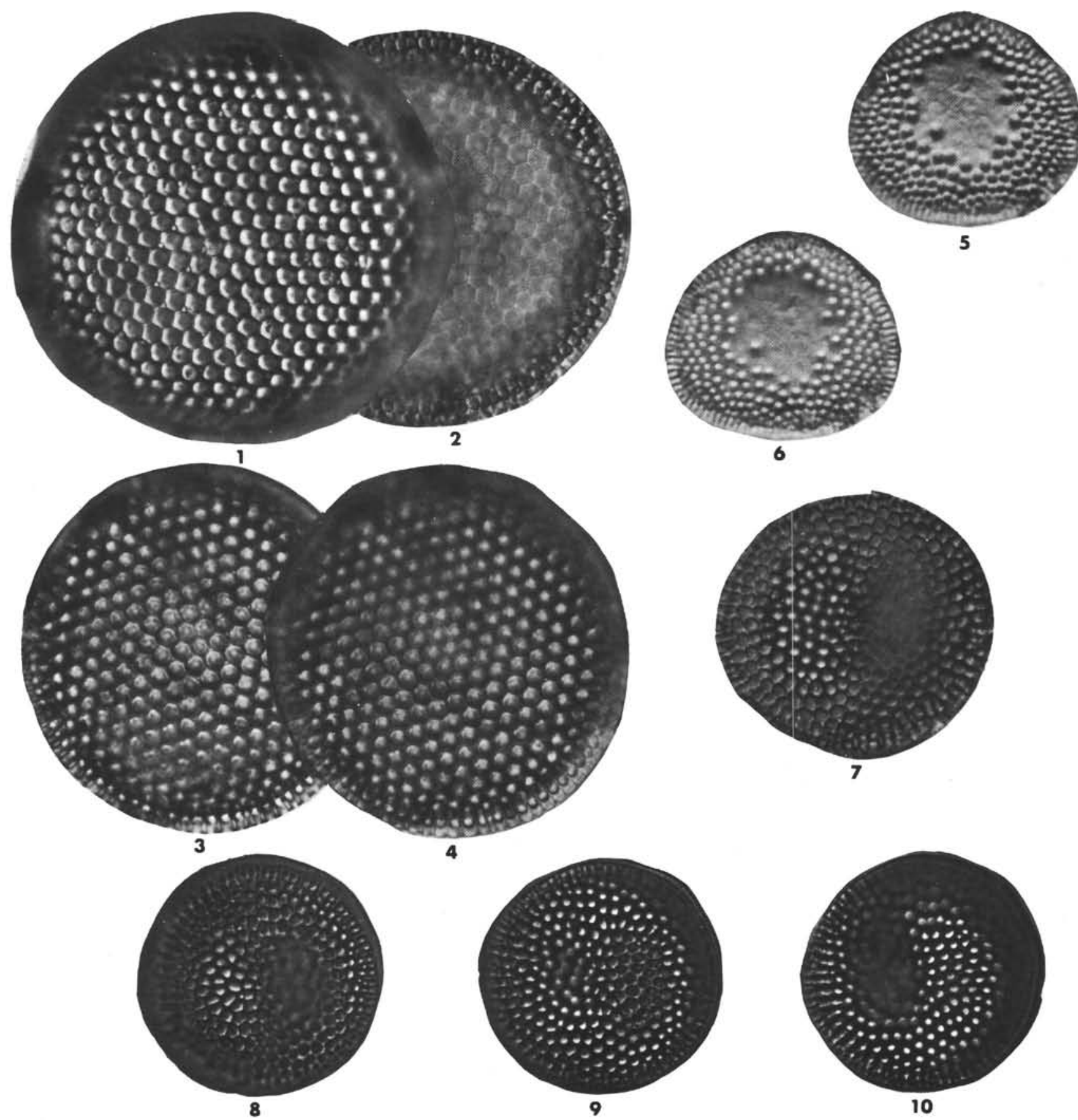

Plate 4. 1-4. Coscinodiscus kolbei Jousé, $\times 1000$, Sample 594-15-2, 4-5 cm. 5-6. Cosmiodiscus insignis $\mathrm{f}$. triangula Jousé, Sample 594-21-5, $4-5 \mathrm{~cm}$. 7-10. Coscinodiscus yabei Kanaya, $\times 1000$, Sample 594-47-1, 4-5 cm. 


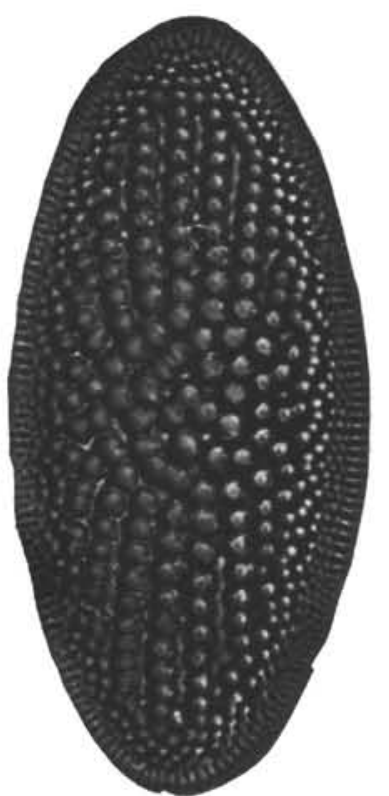

1

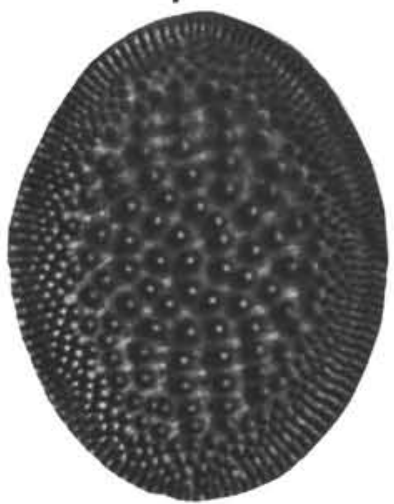

5

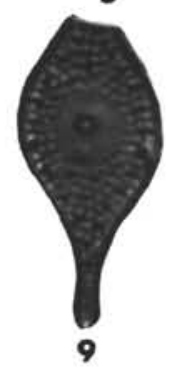

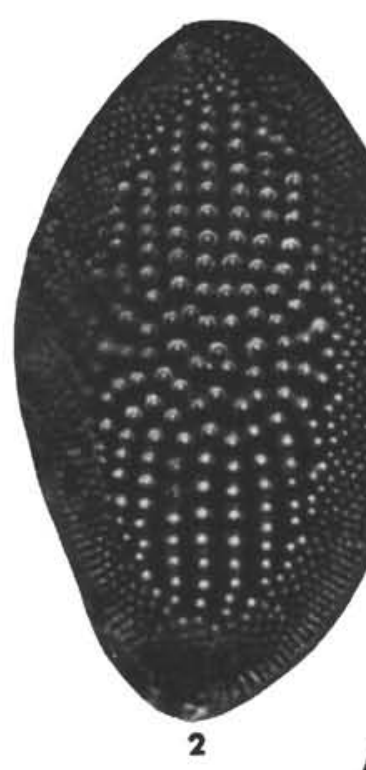

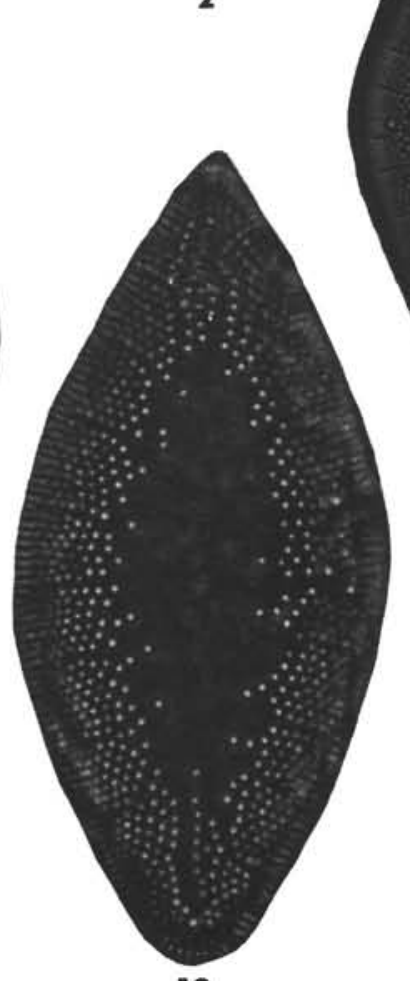

10
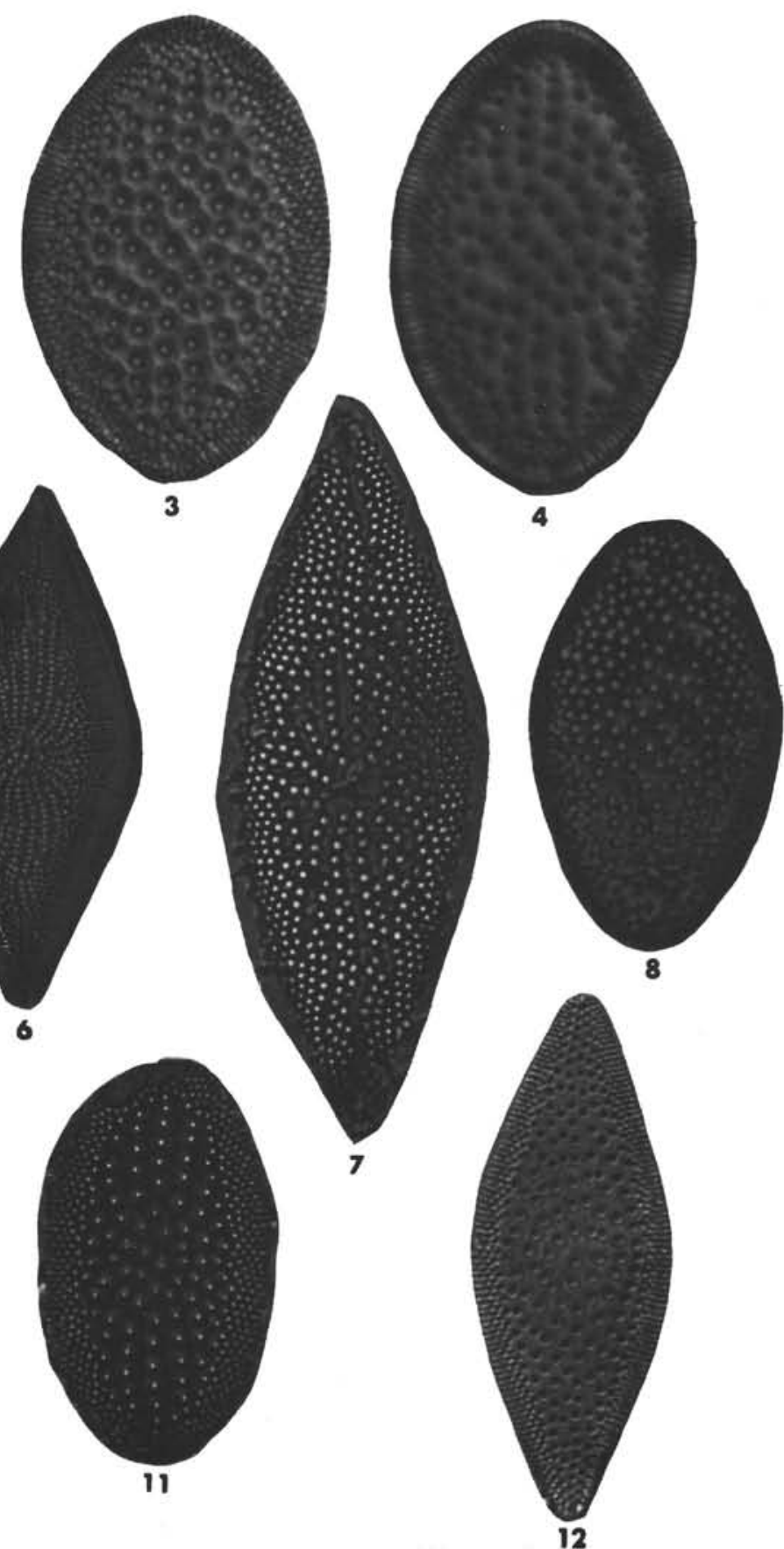

Plate 5. 1-4, 11. Coscinodiscus lewisianus Greville, $\times 1000,(1-2)$ Sample 594A-15-2, 4-5 cm, $(3-4,11)$ Sample 594-52-2, 4-5 cm. 5. Coscinodiscus lewisianus var. robustus Barron, $\times 1000$, Sample $594 \mathrm{~A}-15-2,4-5 \mathrm{~cm}$. 6-7. Actinocyclus ellipticus var. spiralis (Grunow) Barron, $(6) \times 1000$, (7) $\times 1500$, Sample 594A-16-2, 4-5 cm. 8. Actinocyclus ellipticus Grunow, $\times 1500$, Sample 594-28-2, 4-5 cm. 9. Cymatosira sp., $\times 1500$, Sample 594-31-5, 4-5 cm. 10. Cestodiscus peplum Brun, $\times 1000$, Sample 594A-17-2, 4-5 cm. 12. Coscinodiscus rhombicus Castracane. $\times 1000$, Sample $594-47-1,4-5 \mathrm{~cm}$. 


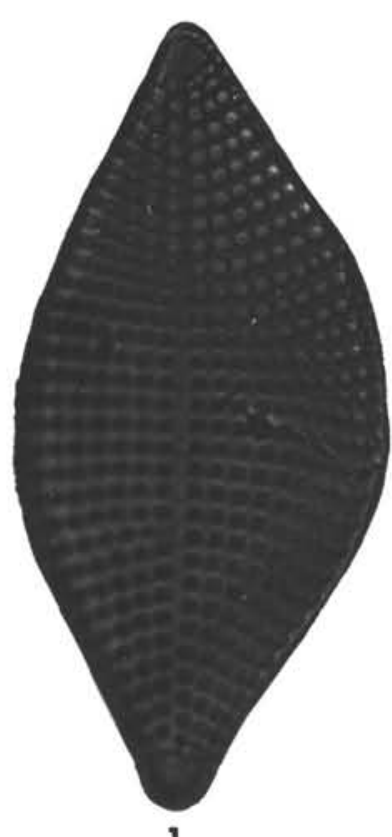

1

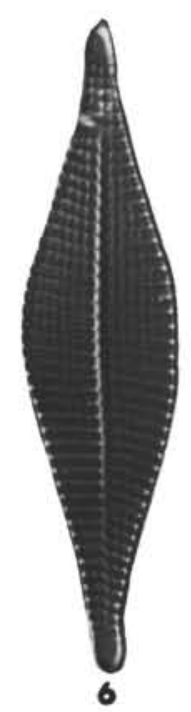

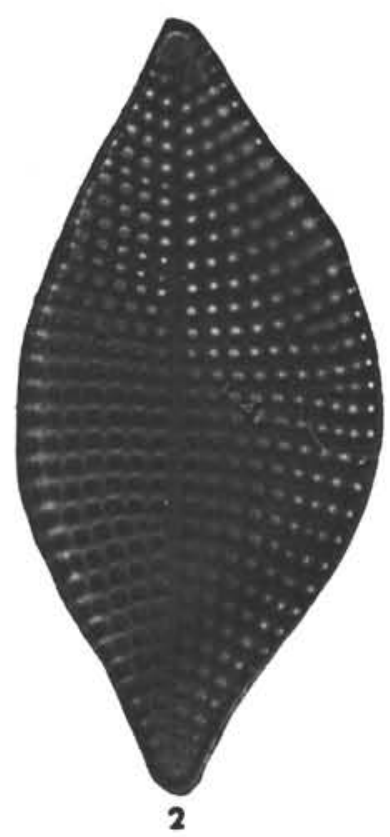
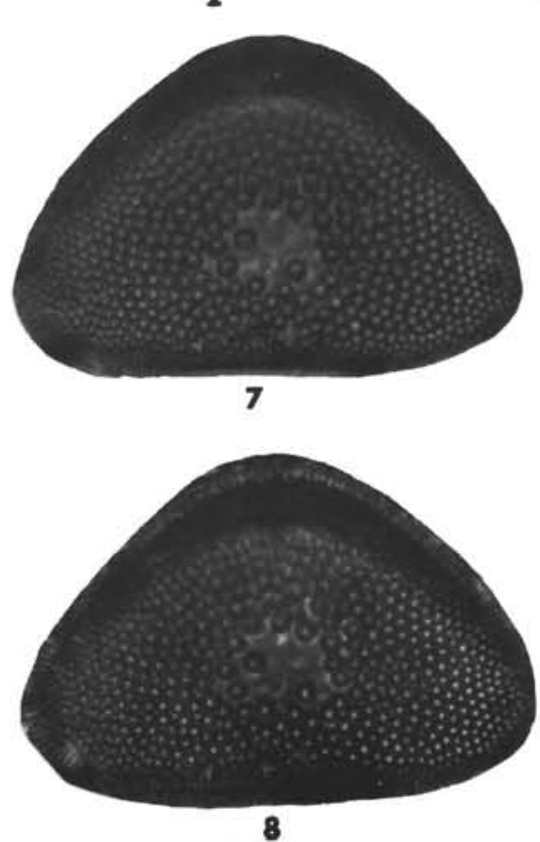
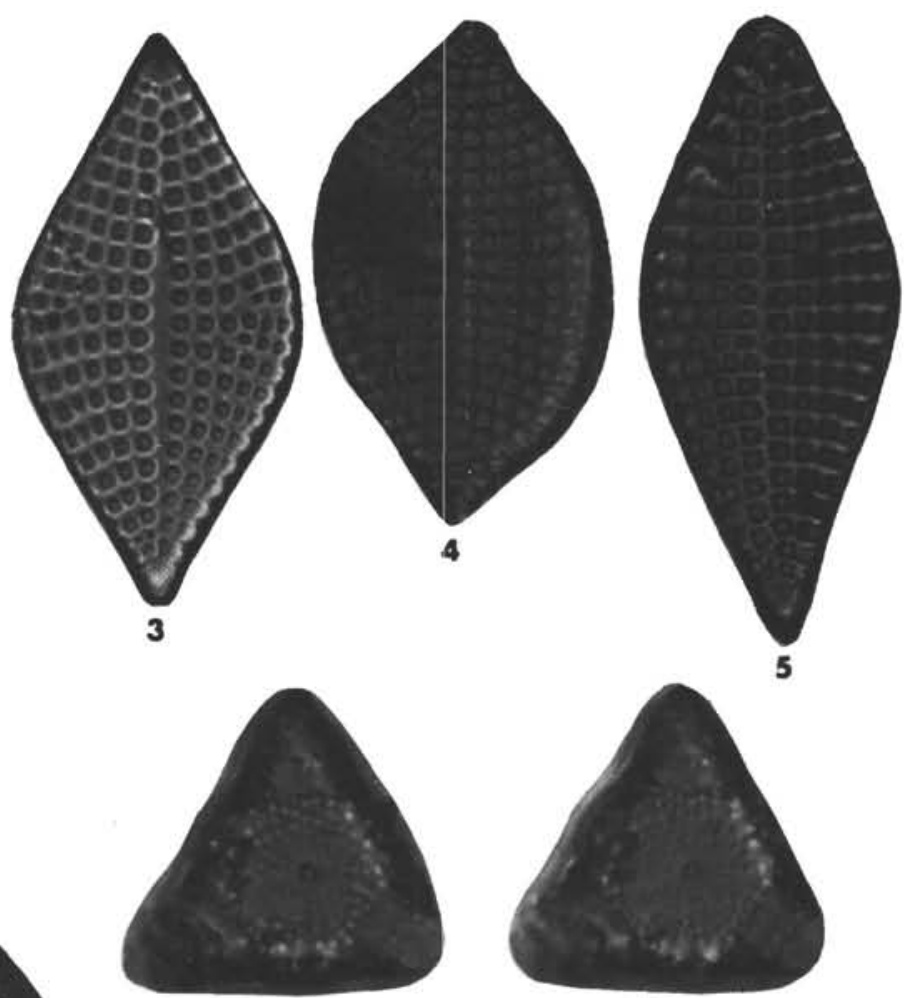

9

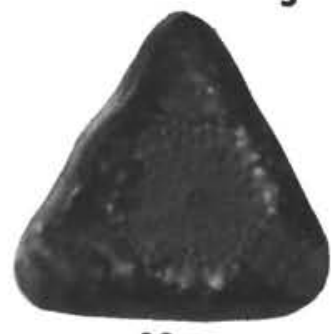

10

Plate 6. 1-3. Rhaphoneis amphiceros Ehrenberg, $\times 1000$, (1-2) Sample 594A-15-2, 4-5 cm, (3) Sample 594A-17-2, 4-5 cm. 4-5. Rhaphoneis sp.

2, $\times 1000$, (4) Sample 594A-15-2, 4-5 cm, (5) Sample 594A-16-2, 4-5 cm. 6. Rhaphoneis parilis Hanna, $\times 1000$, Sample 594A-17-2, 4-5 cm. 7-8. Cosmiodiscus insignis f. triangula Jousé, $\times 1000$, Sample $594-21-5,4-5 \mathrm{~cm}$. 9-10. Lithodesmium reynoldsii Barron, $\times 1500$, Sample 594-29-5, 4-5 cm. 11. Coscinodiscus praenitidus Fenner, $\times 1500$, Sample 594-21-2, 4-5 cm. 